This is an electronic reprint of the original article. This reprint may differ from the original in pagination and typographic detail.

\author{
Author(s): Runtti, Hanna; Luukkonen, Tero; Niskanen, Mikko; Tuomikoski, Sari; Kangas, Teija; \\ Tynjälä, Pekka; Tolonen, Emma-Tuulia; Sarkkinen, Minna; Kemppainen, Kimmo; Rämö, \\ Jaakko; Lassi, Ulla
}

Title: $\quad$ Sulphate removal over barium-modified blast-furnace-slag geopolymer

Year: $\quad 2016$

Version:

Please cite the original version:

Runtti, H., Luukkonen, T., Niskanen, M., Tuomikoski, S., Kangas, T., Tynjälä, P., Tolonen, E.-T., Sarkkinen, M., Kemppainen, K., Rämö, J., \& Lassi, U. (2016). Sulphate removal over barium-modified blast-furnace-slag geopolymer. Journal of Hazardous Materials, 317, 373-384. https://doi.org/10.1016/j.jhazmat.2016.06.001

All material supplied via JYX is protected by copyright and other intellectual property rights, and duplication or sale of all or part of any of the repository collections is not permitted, except that material may be duplicated by you for your research use or educational purposes in electronic or print form. You must obtain permission for any other use. Electronic or print copies may not be offered, whether for sale or otherwise to anyone who is not an authorised user. 
1

2

3

\title{
Sulphate removal over barium-modified blast-furnace-slag geopolymer
}

Hanna Runtti ${ }^{a}$, Tero Luukkonen ${ }^{b}$, Mikko Niskanen $^{a}$, Sari Tuomikoski ${ }^{a}$, Teija Kangas ${ }^{a}$, Pekka Tynjäläc, Emma-Tuulia Tolonen ${ }^{\mathrm{a}, \mathrm{b}}$, Minna Sarkkinen ${ }^{\mathrm{b}}$, Kimmo Kemppainen $^{\mathrm{b}}$, Jaakko Rämö ${ }^{\mathrm{a}}$ \& Ulla Lassi ${ }^{* a, c}$

${ }^{a}$ University of Oulu, Research Unit of Sustainable Chemistry, P.O. Box 3000, FI-90014 University of Oulu, Finland.

${ }^{b}$ Kajaani University of Applied Sciences, P.O. Box 52, Fl-87101 Kajaani, Finland.

${ }^{c}$ University of Jyvaskylä, Kokkola University Consortium Chydenius, Unit of Applied Chemistry, Talonpojankatu 2B, Fl-67100 Kokkola, Finland.

*Corresponding author: E-mail: ulla.lassi@oulu.fi; tel. +35840029 4090

\begin{abstract}
Blast-furnace slag and metakaolin were geopolymerised, modified with barium or treated with a combination of these methods in order to obtain an efficient $\mathrm{SO}_{4}{ }^{2-}$ sorbent for mine water treatment. Of prepared materials, barium-modified blast-furnace slag geopolymer (Ba-BFS-GP) exhibited the highest $\mathrm{SO}_{4}{ }^{2-}$ maximum sorption capacity (up to $119 \mathrm{mg} \mathrm{g}^{-1}$ ) and it compared also favourably to materials reported in the literature. Therefore, Ba-BFS-GP was selected for further studies and the factors affecting to the sorption efficiency were assessed. Several isotherms were applied to describe the experimental results of Ba-BFS-GP and the Sips model showed the best fit. Kinetic studies showed that the sorption process follows the pseudo-second-order kinetics. In the dynamic removal experiments with columns, total $\mathrm{SO}_{4}{ }^{2-}$ removal was observed initially when treating mine effluent. The novel modification method of geopolymer material proved to be technically suitable in achieving extremely low concentrations of $\mathrm{SO}_{4}{ }^{2-}\left(<2 \mathrm{mg} \mathrm{L}^{-1}\right)$ in mine effluents.
\end{abstract}

Keywords: blast-furnace slag, metakaolin, geopolymer, adsorption, sulphate 
${ }_{8}^{7}$ Sulphate $\left(\mathrm{SO}_{4}{ }^{2-}\right)$ is a common anion in both natural water and industrial wastewater, such as acid ${ }_{9} 4$ mine drainage. Natural sources of $\mathrm{SO}_{4}{ }^{2-}$ include the chemical weathering of sulphur-containing necessary mineral for several organisms. However, high concentrations of $\mathrm{SO}_{4}{ }^{2-}$ in aqueous environments can cause the mineralisation of water, corrosion of reinforced steel, scaling of equipment and damage to mammals as well as endangering human health [1-4]. Under anaerobic conditions, $\mathrm{SO}_{4}{ }^{2-}$ can be reduced to hydrogen sulphide $\left(\mathrm{H}_{2} \mathrm{~S}\right)$ by sulphate-reducing bacteria. $\mathrm{H}_{2} \mathrm{~S}$ is dangerous to environmental ecosystems due to its reactivity, toxicity and corrosivity $[1,4]$.

In Finland, the $\mathrm{SO}_{4}{ }^{2-}$ limit in drinking water is set at $250 \mathrm{mg} \mathrm{L}^{-1}$. However, the recommended maximum concentration is even lower $\left(150 \mathrm{mg} \mathrm{L}^{-1}\right)$ to ensure that water pipes are not damaged [5]. Environmental agencies in many countries have set the maximum $\mathrm{SO}_{4}{ }^{2-}$ concentration between 250 and $500 \mathrm{mg} \mathrm{L}^{-1}$ for both mine drainage and industrial effluents $[2,6]$. When there is no established limit for $\mathrm{SO}_{4}{ }^{2-}$, limits for total dissolved solids (TDS) are usually defined, which means that $\mathrm{SO}_{4}{ }^{2-}$ concentrations must comply with the TDS values [7]. In many countries, increasingly strict legislation has been introduced to control water pollution, so there is a need for effective $\mathrm{SO}_{4}{ }^{2-}$ removal technologies.

The processes for $\mathrm{SO}_{4}{ }^{2-}$ removal from wastewater include biological treatment with sulphatereducing bacteria, membrane filtration (e.g. reverse osmosis), adsorption and/or ion exchange and chemical precipitation as gypsum, barium sulphate or ettringite. However, these methods suffer from limitations. For example, precipitation produces a large amount of potentially toxic sludge. Low concentrations (approx. 1200 to $2000 \mathrm{mg} \mathrm{L}^{-1}$ ) cannot be removed by lime precipitation because of the solubility of the $\mathrm{CaSO}_{4}$ that is produced $[2,8,9]$. In addition, biological treatment and ion exchange are costly $[2,3,10,11]$. An adsorption system has the potential to be used in a so-called hybridsystem with precipitation, in which the remaining sulphate concentrations after the precipitation process could be removed via adsorption.

Adsorption may be preferred for $\mathrm{SO}_{4}{ }^{2-}$ removal due to its simplicity, effectiveness and low cost $[11,12]$. Suggested sorbents have included, for example, activated carbon [13], fly ash [14], limestone 

nano-alumina [22], soils [23-25] and waste materials [15].

Geopolymers are amorphous or partly crystalline inorganic polymers with a three-dimensional negatively charged framework structure, which is similar to zeolite [26-31]. They can be prepared at ambient or slightly elevated temperatures by the hydrothermal conversion of a solid aluminosilicate material, e.g. metakaolin [30, 32, 33], blast-furnace slag [34] or fly ash [29, 35-38] with an alkali hydroxide and/or silicate solution. In this study, blast-furnace slag (BFS) and metakaolin (MK) were used as a raw material for geopolymerisation. BFS is a residue product of smelting iron ore in a blast furnace and MK is a dehydroxylated form of the naturally occurring clay mineral kaolinite. BFS and MK are good raw material candidates for preparing geopolymers due to their abundance and easy availability $[33,34,39,40]$.

The series of geochemical reactions that comprise this process are not exactly known, but it has been suggested that they include mineral dissolution, aluminosilicate polycondensation and structural re-organisation [28, 29, 41-43]. Geopolymers possess permanent negative charges on Al on their structure that are balanced by exchangeable cations (e.g. $\mathrm{Na}^{+}, \mathrm{K}^{+}, \mathrm{Li}^{+}, \mathrm{Ba}^{2+}$ ) [43]. They have a high cation exchange capacity, which has been applied for the removal of metal(loid)s [32, 33, 35, 38, 44, 45], dyes [29] and ammonium [46], but there are no studies on $\mathrm{SO}_{4}{ }^{2-}$ removal to our knowledge. Because geopolymers have a low affinity for anions, a chemical modification is needed to apply a sorbent for anionic $\mathrm{SO}_{4}{ }^{2-}$ removal. In literature, it has been reported that the chemical modification with inorganic salts such as $\mathrm{NaCl}, \mathrm{CaCl}_{2}, \mathrm{BaCl}_{2}$ or $\mathrm{FeCl}_{3}$ improves properties of zeolites and increase its efficiency in water treatment [47-49]. In the present study, a similar approach was applied for geopolymer modification. In the case of anion removal, the modification has been reported to for example create an oxi-hydroxide adsorption layer on the surface and change the surface charge (from negative to positive) $[49,50]$. These changes allow to form stable complexes with anions in solution. In the present study, the $\mathrm{BaCl}_{2}$ modification was expected to impregnate $\mathrm{Ba}$ in the framework structure of geopolymers and subsequently enable the surface precipitation or complexation of sulphate.

In this study, the effects of geopolymerisation, barium modification and a combined treatment on metakaolin (MK) and blast-furnace slag (BFS) were studied in order to develop an efficient $\mathrm{SO}_{4}{ }^{2-}$ 
sorbent for mine effluent. Comparative experiments were first performed for synthetic water (model solution). The influence of initial $\mathrm{pH}$, initial $\mathrm{SO}_{4}{ }^{2-}$ concentration, sorbent dosage, contact time and temperature was studied. In addition, adsorption isotherms, kinetics and thermodynamic parameters were studied. Column studies were also performed for the most promising sorbent material: bariummodified BFS geopolymer (Ba-BFS-GP).

\section{Experimental}

\subsection{Materials}

BFS and MK were obtained from Finnish suppliers. Technical grade sodium hydroxide (VWR International) and sodium silicate (VWR International, $\mathrm{SiO}_{2}: \mathrm{Na}_{2} \mathrm{O}=3.1-3.4$ ) were used for the synthesis of geopolymers. $\mathrm{NaCl}$ and $\mathrm{BaCl}_{2}$ were used in chemical modifications. $\mathrm{A}$ stock solution of $\mathrm{SO}_{4}{ }^{2-}$ was prepared by dissolving $\mathrm{Na}_{2} \mathrm{SO}_{4}$ (VWR 99,9\%) in ultrapure water and further diluted to concentrations required for the experiments. The $\mathrm{pH}$ of the solution was adjusted through the addition of $\mathrm{HCl}$ and/or $\mathrm{NaOH}$ (FF-Chemicals).

A mine effluent (settled drainage water treated with ferric sulphate) sample was obtained from an underground gold mine and it was characterized earlier [44].

\subsection{Geopolymerisation}

An alkaline solution containing $10 \mathrm{M} \mathrm{NaOH}$ and sodium silicate $\left(\mathrm{SiO}_{2}: \mathrm{Na}_{2} \mathrm{O}=3.1-3.4\right)$ in a weight ratio of 1:1 was prepared $24 \mathrm{~h}$ before use. BFS or MK was mixed with the alkaline solution in a weight ratio of $3: 2$ or 1.3:1, respectively. The mixtures were mixed for 15 minutes, vibrated for 2 minutes and allowed to consolidate for 3 days at room temperature. The resulting solid material was crushed to a particle size of 63-125 $\mu \mathrm{m}$ or $0.5-1 \mathrm{~mm}$ for batch (equilibrium) and dynamic (non-equilibrium) experiments, respectively. Materials were washed with ultrapure water, dried at $105^{\circ} \mathrm{C}$ and stored in a desiccator. 


\subsection{Chemical modification}

5

62

7

$8^{3}$

The materials $(5 \mathrm{~g})$ were mixed with $1 \mathrm{M} \mathrm{NaCl}$ solution $(50 \mathrm{~mL})$ for $24 \mathrm{~h}$, filtered, rinsed with deionised water and dried at $105{ }^{\circ} \mathrm{C}$ to ensure that all the ion exchange sites were in the $\mathrm{Na}$ form. Barium modification was conducted by mixing the material $(5 \mathrm{~g})$ in a $1 \mathrm{M} \mathrm{BaCl}$ solution $(100 \mathrm{~mL})$ for $16 \mathrm{~h}$, filtering, rinsing with deionised water and drying at $105^{\circ} \mathrm{C}$. The materials were ground and stored in a desiccator before use.

\subsection{Characterisation of the sorbent}

The specific surface area, total pore volume and average pore size were determined from nitrogen adsorption-desorption isotherms at the temperature of liquid nitrogen $\left(-196{ }^{\circ} \mathrm{C}\right)$ using a Micromeritics ASAP 2020 instrument. The X-ray diffraction (XRD) patterns of materials were obtained using a PanAnalytical Xpert Pro diffractometer, and chemical compositions were determined using a PanAnalytical Minipal 4 X-ray fluorescence (XRF) spectrometer. Fourier Transform Infrared Spectroscopy (FTIR) spectra of the sorbent were collected using a Perkin Elmer Spectrum One spectrometer.

\subsection{Batch sorption experiments}

In the batch sorption experiments the system was allowed to reach the sorption equilibrium. The screening of potential sorbents Ba-modified metakaolin (Ba-MK), Ba-modified metakaolin geopolymer (Ba-MK-GP), Ba-modified blast-furnace slag (Ba-BFS) and Ba-modified blast-furnace-slag geopolymer (Ba-BFS-GP) was performed at different initial $\mathrm{pH}$ values in mine effluent. Initial $\mathrm{pH}$ was adjusted by using $\mathrm{HCl}$ and/or $\mathrm{NaOH}$. Ba-BFS-GP was selected for further experiments: the effects of initial $\mathrm{SO}_{4}{ }^{2-}$ concentration, sorbent dosage, temperature and contact time were studied. The studied parameters are shown in Table 1. Samples were filtrated through $0.45 \mu \mathrm{m}$ filter paper (Sartorius Stedim Biotech) or separated using a centrifuge. $\mathrm{SO}_{4}{ }^{2-}$ concentration was determined in the filtrate solution via ion 
Table 1. Parameters for testing the effects of initial $\mathrm{pH}$, initial $\mathrm{SO}_{4}{ }^{2-}$ concentration, sorbent dosage, contact time and temperature on $\mathrm{SO}_{4}{ }^{2-}$ removal efficiency.

\begin{tabular}{|c|c|c|c|c|c|c|c|}
\hline Parameter & $\begin{array}{c}\text { Initial pH } \\
\text { of } \\
\text { solution }\end{array}$ & $\begin{array}{c}\text { Initial } \mathrm{SO}_{4}{ }^{2-} \\
\text { concentration } \\
{\left[\mathrm{mg} \mathrm{L}^{-1}\right]}\end{array}$ & $\begin{array}{c}\text { Sorbent } \\
\text { dosage } \\
{\left[\mathrm{g} \mathrm{L}^{-1}\right]} \\
\end{array}$ & Contact time & $\begin{array}{c}\text { Temperature } \\
{\left[{ }^{\circ} \mathrm{C}\right]}\end{array}$ & Sorbent & $\begin{array}{l}\text { Water } \\
\text { matrix }\end{array}$ \\
\hline Effect of initial pH & $4,6,8,10$ & $850-870$ & 5 & $24 \mathrm{~h}$ & 22 & $\begin{array}{c}\text { Ba-MK, } \\
\text { Ba-BFS, } \\
\text { Ba-MK-GP, } \\
\text { Ba-BFS-GP }\end{array}$ & $\begin{array}{c}\text { Mine } \\
\text { effluent }\end{array}$ \\
\hline $\begin{array}{l}\text { Effect of initial } \mathrm{SO}_{4}{ }^{2-} \\
\text { concentration }\end{array}$ & $7-8$ & $50-1000$ & 5 & $24 \mathrm{~h}$ & 22 & Ba-BFS-GP & Synthetic \\
\hline \multirow{2}{*}{$\begin{array}{l}\text { Effect of sorbent } \\
\text { dosage }\end{array}$} & $7-8$ & 1200 & $0.5-15$ & $3 \mathrm{~h}$ & $10,22,40$ & Ba-BFS-GP & Synthetic \\
\hline & $7-8$ & 865 & $0.5-25$ & $24 \mathrm{~h}$ & 22 & Ba-BFS-GP & $\begin{array}{c}\text { Mine } \\
\text { effluent }\end{array}$ \\
\hline \multirow[t]{2}{*}{ Effect of contact time } & $7-8$ & 1100 & 5 & $1 \mathrm{~min}-24 \mathrm{~h}$ & 22 & Ba-BFS-GP & Synthetic \\
\hline & $7-8$ & 853 & 5 & $1 \mathrm{~min}-24 \mathrm{~h}$ & 22 & Ba-BFS-GP & $\begin{array}{c}\text { Mine } \\
\text { effluent }\end{array}$ \\
\hline
\end{tabular}

\subsection{Dynamic sorption experiments}

In the dynamic experiments, the sorption was performed in the non-equilibrium state. The experiments were performed using a plastic column (diameter $44.0 \mathrm{~mm}$, height $98.8 \mathrm{~mm}$, volume $0.15 \mathrm{~L}$ ), which was loaded with $30.45 \mathrm{~g}$ of Ba-BFS-GP with a particle size of $0.5-1 \mathrm{~mm}$. The sorbent bed height was $2.0 \mathrm{~cm}$ with a bed volume of $30.41 \mathrm{~cm}^{3}$. Mine effluent with $820 \mathrm{mg} \mathrm{L}^{-1} \mathrm{SO}_{4}{ }^{2-}$ was pumped through the column by a peristaltic pump. The flow of effluent was adjusted to 0.24 or $0.85 \mathrm{~L} \mathrm{~h}^{-1}$, corresponding to 7.60 and 2.15 min empty bed contact time, respectively. Samples were taken from the outlet of the column at different time intervals. 


\subsection{Barium leaching test}

To evaluate the stability of impregnated barium in Ba-BFS-GP, $0.125 \mathrm{~g}$ of material was added to $25 \mathrm{~mL}$ mine effluent and shaken $24 \mathrm{~h}$. Barium leaching experiments were also performed with distilled water by weighing 0.005 or $0.125 \mathrm{~g}$ of Ba-BFS-GP to $10 \mathrm{~mL}$ or $25 \mathrm{~mL}$ of distilled water, respectively. Samples were filtered through $0.45 \mu \mathrm{m}$ filter paper, and the barium concentration was analysed using inductively coupled plasma emission spectrometers (Thermo Electron IRIS Intrepid II XDL Duo or PerkinElmer Optima 5300 DV ICP-OES instrument) according to the SFS-EN ISO 11885 standard.

\subsection{Adsorption isotherms}

Bi-Langmuir [51], Sips [52], Redlich-Peterson (R-P) [53] and Toth [54] isotherms are presented in Equations 1-4, respectively. Isotherm parameters were obtained using nonlinear regression with the Microsoft Excel solver tool (GRG nonlinear).

$q_{e}=\frac{q_{m_{1}} b_{L_{1}} C_{e}}{1+b_{L_{1}} C_{e}}+\frac{q_{m_{2}} b_{L_{2}} C_{e}}{1+b_{L_{2}} C_{e}}$

where $q_{m 1}$ and $q_{m 2}$ are the maximum adsorption capacities $\left(\mathrm{mg} \mathrm{g}^{-1}\right)$ of two different adsorption sites. Similarly, $b_{L 1}$ and $b_{L 2}$ represent the energies $\left(\mathrm{mg} \mathrm{g}^{-1}\right)$ of adsorption at these sites.

$q_{e}=\frac{q_{m}\left(b_{S} C_{e}\right)^{n_{S}}}{1+\left(b_{S} C_{e}\right)^{n_{S}}}$

where $b_{S}\left(\mathrm{~L} \mathrm{mg}^{-1}\right)$ is a constant related to the adsorption energy and $n_{s}$ is a dimensionless constant characterising the heterogeneity of the system.

$q_{e}=\frac{K_{R} C_{e}}{1+a_{R} C_{e}^{\beta}}$, 
where $K_{R}\left(\mathrm{dm}^{3} \mathrm{~g}^{-1}\right)$ and $a_{R}\left(\mathrm{dm}^{3} \mathrm{mg}^{-1}\right)$ are R-P isotherm constants and $\beta$ is an exponent, the value of which lies between 0 and 1.

$q_{e}=\frac{q_{T h} K_{T h} C_{e}}{\left[1+\left(K_{T h} C_{e}\right)^{T h}\right]^{\frac{1}{T h}}}$

where $q_{m}\left(\mathrm{mg} \mathrm{g}^{-1}\right)$ is the monolayer adsorptive uptake, $K_{T h}\left(\mathrm{~L} \mathrm{mg}^{-1}\right)$ is the Toth isotherm constant and Th is the dimensionless Toth isotherm exponent, which characterises the heterogeneity of the system. The residual root mean square error (RMSE) and chi-square test $\left(\chi^{2}\right)$ were used to assess the error:

$\mathrm{RMSE}=\sqrt{\frac{1}{n-p} \sum_{i=1}^{n}\left(q_{e(\exp )}-q_{e(c a l c)}\right)^{2}}$

$\chi^{2}=\sum_{n=1}^{n} \frac{\left(q_{e(e x p)}-q_{e(c a l c)}\right)^{2}}{q_{e(c a l c)}}$

where $n$ is the number of experimental data, $p$ is the number of parameters whilst $q_{e(\exp )}$ and $q_{e(c a l c)}$ are experimental and calculated values of adsorption capacity in equilibrium.

\subsection{Kinetic modelling}

The kinetics of the adsorption processes were studied using the pseudo-first-order [55], the pseudosecond-order [56] and the Elovich [57] kinetic models:

$\log \left(q_{e}-q_{t}\right)=\log q_{e}-\frac{k_{f}}{2.303} t$

$\frac{t}{q_{t}}=\frac{1}{k_{s} q_{e}^{2}}+\frac{1}{q_{e}} \mathrm{t}$, 
$\mathrm{q}=\frac{1}{\beta} \ln \left(v_{0} \beta+\frac{1}{\beta} \ln t\right)$

2

8

where $q_{e}$ and $q_{t}$ are the amounts of $\mathrm{SO}_{4}{ }^{2-}$ sorbed $\left(\mathrm{mg} \mathrm{g}^{-1}\right)$ at equilibrium and at time $t(\min )$, respectively. $k_{f}\left(\mathrm{~min}^{-1}\right), k_{s}\left(\mathrm{~g} \mathrm{mg}^{-1} \mathrm{~min}^{-1}\right)$ and $U_{0}\left(\mathrm{mg} \mathrm{g}^{-1} \mathrm{~min}^{-1}\right)$ are the pseudo-first-order, pseudosecond-order and Elovich rate constants, respectively. The Elovich parameter $\beta\left(\mathrm{g} \mathrm{mg}^{-1}\right)$ is related to the extent of surface coverage and activation energy for chemisorption.

The diffusion mechanism was analysed using the intraparticle diffusion model [58]:

$q_{t}=k_{i d} t^{1 / 2}+\mathrm{C}$

where $k_{\text {id }}\left(\mathrm{mg} \mathrm{g}^{-1} \mathrm{~min}^{-1 / 2}\right)$ is the intraparticle diffusion on the rate determining step and $\mathrm{C}$ is the intercept related to the thickness of the boundary layer.

\subsection{Sorption thermodynamics}

The change in free energy $(\Delta G)$, enthalphy $(\Delta H)$ and entropy $(\Delta S)$ were determined to describe the sorption of $\mathrm{SO}_{4}{ }^{2-}$ :

$\Delta G=-R T \ln \left(K_{c}\right)$

$$
K_{c}=\frac{q}{C_{e}}
$$

$\ln K=\frac{\Delta S}{R}-\frac{\Delta H}{R T}$

where, $R$ is the universal gas constant $\left(8.314 \mathrm{~J} \mathrm{~mol}^{-1} \mathrm{~K}^{-1}\right), T$ is the temperature $(\mathrm{K})$, and $K_{c}$ is the equilibrium constant. 


\section{Results and discussion}

\subsection{Sorbent characterisation}

Specific surface area, average pore size and volumes (Table 2) of MK increase as a result of geopolymerisation. However, with BFS, the surface area and pore volumes increase whereas pore size decreases during geopolymerisation. Barium modification has no significant effect on surface area, pore sizes and volumes of geopolymerised BFS.

Table 2. Specific surface areas, pore sizes and volumes of sorbents.

\begin{tabular}{lcccc}
\hline Sorbent & $\begin{array}{c}\text { Specific surface } \\
\text { area }\left[\mathrm{m}^{2} \mathrm{~g}^{-1}\right]\end{array}$ & $\begin{array}{c}\text { Average pore } \\
\text { size[nm] }\end{array}$ & $\begin{array}{c}\mathrm{V}_{\text {macro+meso }} \\
{\left[\mathrm{cm}^{3} \mathrm{~g}^{-1}\right]}\end{array}$ & $\begin{array}{c}\mathrm{V}_{\text {micro }} \\
{\left[\mathrm{cm}^{3} \mathrm{~g}^{-1}\right]}\end{array}$ \\
\hline MK & 11.5 & 18.2 & 0.047 & 0.005 \\
MK-GP & 22.4 & 31.0 & 0.165 & 0.008 \\
BFS & 2.79 & 12.7 & 0.008 & 0.001 \\
BFS-GP & 64.5 & 5.93 & 0.070 & 0.025 \\
BFS-GP-Ba & 63.1 & 6.32 & 0.070 & 0.030 \\
\hline
\end{tabular}

Macropore: $\mathrm{d}_{0}>50 \mathrm{~nm}$, Mesopore: $2 \mathrm{~nm} \leq \mathrm{d}_{0} \leq 50 \mathrm{~nm}$, Micropore: $\mathrm{d}_{0} \leq 2 \mathrm{~nm}$.

Table 3 shows the chemical composition of BFS, BFS-GP and Ba-BFS-GP. The main components of BFS are calcium, silicon, magnesium, aluminium and sulphur. In addition, sorbents included some other impurities. Aluminium and silicon contents decrease while $\mathrm{Na}$ content increases after geopolymerisation. In addition, the loss on ignition (L.O.I.) increases due to the increased water content. The decrease of $\mathrm{CaO}$ as BFS is converted into BFS-GP is possibly due to the dissolution of gehlenite and other phases [27]. In Ba-BFS-GP, Na ions are completely replaced by $\mathrm{Ba}$, as signified by corresponding concentrations.

Table 3. Main chemical constituents as determined by XRF.

\begin{tabular}{lccc}
\hline Composition & $\begin{array}{c}\mathrm{BFS} \\
{[\mathrm{w} / \mathrm{w} \%]}\end{array}$ & $\begin{array}{c}\text { BFS-GP } \\
{[\mathrm{w} / \mathrm{w} \%]}\end{array}$ & $\begin{array}{c}\text { Ba-BFS-GP } \\
{[\mathrm{w} / \mathrm{w} \%]}\end{array}$ \\
\hline $\mathrm{CaO}$ & 38.5 & 29.9 & 26.3 \\
$\mathrm{SiO}$ & 27.2 & 25.8 & 26.8 \\
$\mathrm{MgO}$ & 9.4 & 6.4 & 7.1 \\
$\mathrm{Al}_{2} \mathrm{O}_{3}$ & 8.4 & 5.9 & 6.7 \\
$\mathrm{SO}_{3}$ & 3.8 & 2.7 & 0.7 \\
\hline
\end{tabular}




\begin{tabular}{lccc}
\hline $\mathrm{Na}_{2} \mathrm{O}$ & 0.3 & 8.0 & 0.0 \\
$\mathrm{Ba}$ & 0.0 & 0.0 & 17.3 \\
Other* & 2.9 & 2.4 & 0.0 \\
L.O.I. & 0.5 & 12.9 & 14.5 \\
Sum & 90.9 & 93.9 & 99.4 \\
\hline
\end{tabular}

*Including $\mathrm{Ti}_{1} \mathrm{Fe}_{2} \mathrm{O}_{3}, \mathrm{~K}_{2} \mathrm{O}, \mathrm{Mn}$.

The XRD patterns (Fig. 1) of BFS, BFS-GP, and Ba-BFS-GP indicate initially a completely X-ray amorphous structure, formation of hydrotalcite $\left(\mathrm{Mg}_{6} \mathrm{Al}_{2} \mathrm{CO}_{3}(\mathrm{OH})_{16} \cdot 4\left(\mathrm{H}_{2} \mathrm{O}\right)\right)$ and haturite $\left(\mathrm{Ca}_{3} \mathrm{SiO}_{5}\right)$ after geopolymerisation and further formation of witherite $\left(\mathrm{BaCO}_{3}\right)$ after Ba-modification.

Figure 1. XRD patterns of blast-furnace slag (BFS), blast-furnace-slag geopolymer (BFS-GP) and barium-modified blast-furnace-slag geopolymer (Ba-BFS-GP) samples. HT = hydrotalcite, HAT = haturite, $\mathrm{W}=$ witherite.

FTIR spectra for BFS, BFS-GP and Ba-BFS-GP are shown in Fig. 2. The peak in the spectra of Ba-BFS-GP at $856 \mathrm{~cm}^{-1}$ is related to the witherite $\left(\mathrm{BaCO}_{3}\right)$ vibration. The bands in the spectra of BFS, Ba-BFS and Ba-BFS-GP appearing at 960, 942, $894 \mathrm{~cm}^{-1}$, respectively, belong to Si-O stretching vibrations [59]. The bands at 1471 and $1391 \mathrm{~cm}^{-1}$ are associated with carbonate vibration in the structure of Ba-BFSGP and Ba-BFS [26]. Carbon dioxide shows a strong band in the area of $2350 \mathrm{~cm}^{-1}$, and thus the band in Ba-BFS-GP could be related to adsorbed carbon dioxide $[60,61]$.

Figure 2. The FTIR spectra of blast-furnace slag (BFS), barium-modified blast-furnace-slag (Ba-BFS) and barium-modified blast-furnace-slag geopolymer (Ba-BFS-GP).

\subsection{Effect of initial pH and screening of sorbents}

The effect of initial $\mathrm{pH}$ on the removal of $\mathrm{SO}_{4}{ }^{2-}$ from mine effluent over BFS-GP, Ba-BFS-GP, Ba-MK and Ba-MK-GP is shown in Fig. 3. Sorption efficiency decreases slightly as the initial pH increases from 4 to 10. This may be due to the competition for the sorption sites by $\mathrm{OH}^{-}$ions at high $\mathrm{pH}[22,62]$. Ba-BFS- 
GP is the most effective sorbent material and it was selected for further study. Sorption efficiency is c.a. $50 \%$ at $\mathrm{pH}$ range $4-10$.

\subsection{Effect of initial $\mathrm{SO}_{4}{ }^{2-}$ concentration}

The effect of initial $\mathrm{SO}_{4}{ }^{2-}$ concentration was investigated with model solutions in the range of 100$1800 \mathrm{mg} \mathrm{L}^{-1}$. The results are presented in Fig. 4. The $\mathrm{SO}_{4}{ }^{2-}$ sorption capacity of Ba-BFS-GP increases as the $\mathrm{SO}_{4}{ }^{2-}$ concentration is increased and reaches a maximum value $\left(90 \mathrm{mg} \mathrm{g}^{-1}\right)$ at about $1200 \mathrm{mg} \mathrm{L}^{-1}$. The initial sharp rise of sorption capacity in Fig. 4 indicates that sorption sites are readily available and the surface becomes saturated as the curve levels off $[22,62]$.

Figure 4. Effect of the initial concentration on the sorption of $\mathrm{SO}_{4}{ }^{2-}$ on Ba-BFS-GP from model solution. Initial pH: 7-8, sorbent dosage: $5 \mathrm{~g} \mathrm{~L}^{-1}$, contact time: $24 \mathrm{~h}$, temperature: $22-23^{\circ} \mathrm{C}$.

\subsection{Effect of sorbent dosage and temperature}

The effect of Ba-BFS-GP dosage on the removal of $\mathrm{SO}_{4}{ }^{2-}$ from model solution and mine effluent are shown in Fig. 5 . In both cases the percentage of $\mathrm{SO}_{4}{ }^{2-}$ removal increases with the increasing sorbent dosage and reaches a saturation level at high doses. This phenomenon could be explained by the increase in surface area and the available sorption sites with an increase in the sorbent dosage [63-65]. The sorbent reached maximum removal of $\mathrm{SO}_{4}{ }^{2}$ at dose $10 \mathrm{~g} \mathrm{~L}^{-1}$ of sorbent, probably due to the of mass transfer resistance of $\mathrm{SO}_{4}{ }^{2-}$ from bulk liquid to the surface of the solid, which becomes important at high sorbent loading. In addition, at $40{ }^{\circ} \mathrm{C}$ the percentage of $\mathrm{SO}_{4}{ }^{2-}$ removal was decreased slightly with the higher dosage $\left(>10 \mathrm{~g} \mathrm{~L}^{-1}\right)$. The higher sorbent dosage results in interference or repulsive forces between binding sites and formation of particle aggregates, 


\subsection{Adsorption isotherms}

Bi-Langmuir, Sips, R-P and Toth isotherm models were applied for the experimental results of Ba-BFSGP (Fig. 6 and Table 4). Comparison of the results for the errors (RMSE, $\mathrm{X}^{2}$ ) and correlation coefficients $\left(R^{2}\right)$ indicated that the $\mathrm{SO}_{4}{ }^{2-}$ sorption onto Ba-BFS-GP from model solution can be best represented by the Sips isotherm. Maximum experimental $\left(q_{m, \text { exp }}\right)$ and theoretical $\left(q_{m, \text { calc }}\right)$ sorption capacities are quite similar. In the case of mine effluent, all studied isotherm models gave practically similar correlation coefficient values $\left(R^{2}: 0.920-0.930\right)$ and errors.

Figure 6. Bi-Langmuir, Sips, Redlich-Peterson and Toth isotherms of $\mathrm{SO}_{4}{ }^{2-}$ sorption on Ba-BFS-GP. a) Model solution: $\mathrm{C}_{0}\left(\mathrm{SO}_{4}{ }^{2-}\right): 100-1800 \mathrm{mg} \mathrm{L}^{-1}$, sorbent dose: $5 \mathrm{~g} \mathrm{~L}^{-1}$. b) Mine effluent: $\mathrm{C}_{0}\left(\mathrm{SO}_{4}{ }^{2-}\right): 865 \mathrm{mg}$ $\mathrm{L}^{-1}$, sorbent dose: $1.3-15 \mathrm{~g} \mathrm{~L}^{-1}$. Initial $\mathrm{pH}$ was $7-8$, contact time $24 \mathrm{~h}$ and temperature $22-23^{\circ} \mathrm{C}$. 
Table 4. Isotherm parameters and errors for the sorption of $\mathrm{SO}_{4}{ }^{2-}$ removal on Ba-BFS-GP.

\begin{tabular}{|c|c|c|c|}
\hline & Constant (unit) & Model solution $^{\text {a) }}$ & Mine effluent ${ }^{b)}$ \\
\hline \multicolumn{4}{|l|}{ Isotherm } \\
\hline Experimental & $q_{m}\left(m g ~ g^{-1}\right)$ & 91.1 & 119.0 \\
\hline \multirow[t]{7}{*}{ Bi-Langmuir } & $\mathrm{q}_{\mathrm{m} 1}\left(\mathrm{mg} \mathrm{g}^{-1}\right)$ & 42.109 & 55.290 \\
\hline & $\mathrm{b}_{\mathrm{L1}}\left(\mathrm{L} \mathrm{mg}^{-1}\right)$ & 0.463 & 0.400 \\
\hline & $\mathrm{q}_{\mathrm{m} 2}\left(\mathrm{mg} \mathrm{g}^{-1}\right)$ & 42.109 & 55.290 \\
\hline & $\mathrm{b}_{\mathrm{L} 2}\left(\mathrm{~L} \mathrm{mg}^{-1}\right)$ & 0.463 & 0.400 \\
\hline & $\mathrm{R}^{2}$ & 0.926 & 0.920 \\
\hline & RMSE & 8.737 & 10.452 \\
\hline & $x^{2}$ & 3.810 & 7.501 \\
\hline \multirow[t]{6}{*}{ Sips } & $\mathrm{q}_{\mathrm{sm}}\left(\mathrm{mg} \mathrm{g}^{-1}\right)$ & 83.691 & 110.580 \\
\hline & $\mathrm{b}_{\mathrm{s}}\left(\mathrm{L} \mathrm{mg}^{-1}\right)$ & 0.482 & 0.400 \\
\hline & $\mathrm{n}_{\mathrm{s}}$ & 2.102 & 1.000 \\
\hline & $\mathrm{R}^{2}$ & 0.951 & 0.920 \\
\hline & RMSE & 6.174 & 9.541 \\
\hline & $x^{2}$ & 1.822 & 7.501 \\
\hline \multirow[t]{6}{*}{ Redlich-Peterson (R-P) } & $K_{R}\left(d m^{3} g^{-1}\right)$ & 48.978 & 57.107 \\
\hline & $a_{R}\left(d^{3} m^{-1}\right)$ & 0.734 & 0.650 \\
\hline & $\beta$ & 0.964 & 0.963 \\
\hline & $\mathrm{R}^{2}$ & 0.931 & 0.929 \\
\hline & RMSE & 7.318 & 8.945 \\
\hline & $x^{2}$ & 3.990 & 7.714 \\
\hline \multirow[t]{6}{*}{ Toth } & $\mathrm{q}_{\mathrm{Th}}\left(\mathrm{mg} \mathrm{g}^{-1}\right)$ & 64.937 & 85.863 \\
\hline & $\mathrm{K}_{\mathrm{Th}}\left(\mathrm{mg} \mathrm{dm}^{-3}\right)^{\mathrm{Th}}$ & 1.391 & 1.593 \\
\hline & Th & 1.042 & 1.043 \\
\hline & $R^{2}$ & 0.932 & 0.930 \\
\hline & RMSE & 7.257 & 8.870 \\
\hline & $x^{2}$ & 3.943 & 7.071 \\
\hline
\end{tabular}

a) Model solution: Initial pH: 7-8, $\mathrm{C}_{0}\left(\mathrm{SO}_{4}{ }^{2-}\right): 100-1800 \mathrm{mg} \mathrm{L}^{-1}, \mathrm{~m}(\mathrm{Ba}-\mathrm{BFS}-\mathrm{GP}): 5 \mathrm{~g} \mathrm{~L}^{-1}$.

b) Mine effluent: Initial pH: 7-8, $\mathrm{C}_{0}\left(\mathrm{SO}_{4}{ }^{2-}\right): 865 \mathrm{mg} \mathrm{L}^{-1}, \mathrm{~m}(\mathrm{Ba}-\mathrm{BFS}-\mathrm{GP}): 1.3-15 \mathrm{~g} \mathrm{~L}^{-1}$.

Contact time: $24 \mathrm{~h}$ and temperature $22-23^{\circ} \mathrm{C}$. 
Table 5. Comparison of adsorption capacity $q_{m}\left(\mathrm{mg} \mathrm{g}^{-1}\right)$ of various sorbents for the removal of $\mathrm{SO}_{4}{ }^{2-}$

2 from aqueous phase.

\begin{tabular}{|c|c|c|c|c|}
\hline Sorbent & $\begin{array}{l}\text { Capacity } \\
\mathrm{q}\left(\mathrm{mg} \mathrm{g}^{-1}\right)\end{array}$ & $\mathrm{pH}$ & Concentration $\left(\mathrm{mg} \mathrm{L}^{-1}\right)$ & Reference \\
\hline Coir pith carbon & $0.06^{a}$ & 4.0 & $20-80$ & [68] \\
\hline Iron sand & $\begin{array}{c}1.15^{\mathrm{b}} \\
\left(12 \mathrm{mmol} \mathrm{g}^{-1}\right)\end{array}$ & - & $20-2000$ & [15] \\
\hline Feldspar & $0.275^{\mathrm{a}}$ & 5.5 & $1-5$ & [5] \\
\hline Pulp and paper waste & $\begin{array}{c}2.786^{\mathrm{b}} \\
\left(29 \mathrm{mmol} \mathrm{g}^{-1}\right)\end{array}$ & - & $20-2000$ & [15] \\
\hline Surfactant-modified palygorskite & $3.24^{b}$ & 4.0 & $20-130$ & [4] \\
\hline $\mathrm{ZnCl}_{2}$ activated coir pith carbon & $4.9^{\mathrm{a}}$ & 4.0 & $20-80$ & [68] \\
\hline $\begin{array}{l}\text { Surfactant-modified } \\
\text { clinoptilolite }\end{array}$ & $\sim 7.0^{\mathrm{a}}$ & - & $96-500$ & [20] \\
\hline$\gamma-\mathrm{Al}_{2} \mathrm{O}_{3}$ & $7.7^{\mathrm{a}}$ & 5.7 & $20-40$ & [69] \\
\hline Surfactant modified coir pith & $8.76^{\mathrm{a}}$ & 2 & $10-50$ & {$[7]$} \\
\hline Raw rice straw & $11.68^{\mathrm{a}}$ & 6.4 & $50-500$ & [1] \\
\hline Flotation fines & $\begin{array}{c}21.23^{\mathrm{b}} \\
\left(221 \mathrm{mmol} \mathrm{g}^{-1}\right)\end{array}$ & - & $20-2000$ & [15] \\
\hline Limestone & $23.7^{\mathrm{a}}$ & $9.6-9.8$ & $588-1100$ & [2] \\
\hline Filter sand & $\begin{array}{c}25.07^{\mathrm{b}} \\
\left(261 \mathrm{mmol} \mathrm{g}^{-1}\right)\end{array}$ & - & $20-2000$ & {$[15]$} \\
\hline Alkali-treated fly ash & $43.0^{\mathrm{a}}$ & - & 200 & [36] \\
\hline Ba-modified zeolite & $\begin{array}{c}64.10^{\mathrm{a}} \\
\left(1.33 \mathrm{meq} \mathrm{g}^{-1}\right)\end{array}$ & 6.0 & $<1000$ & [21] \\
\hline $\begin{array}{l}\text { Epichlorohydrin and } \\
\text { trimethylamine modified rice } \\
\text { straw }\end{array}$ & $74.76^{\mathrm{a}}$ & 6.4 & $50-500$ & [1] \\
\hline $\operatorname{poly}(m$-phenylenediamine) & $108.5^{\mathrm{a}}$ & $1.75-3$ & $50-4000$ & [11] \\
\hline $\begin{array}{l}\text { Ba-modified blast-furnace-slag } \\
\text { geopolymer }\end{array}$ & $119.0^{b}$ & $7-8$ & 865 & This study \\
\hline Chitin-based shrimp shells & $156.0^{\mathrm{a}}$ & 4.5 & 2350 & [70] \\
\hline
\end{tabular}

aLangmuir maximum sorption capacity, $\mathrm{q}_{\mathrm{m} \text {,calc }},{ }^{\mathrm{b}}$ Experimental maximum sorption capacity

\subsection{Effect of contact time}

The effect of contact time on the removal of $\mathrm{SO}_{4}{ }^{2-}$ by Ba-BFS-GP at room temperature is presented in Fig. 7. It can be seen from the curves that the sorption is rapid in the first 10 min while sorption equilibrium is attained at approximately $3 \mathrm{~h}$. The rate of $\mathrm{SO}_{4}{ }^{2-}$ removal was higher at the beginning of the sorption experiment due to a larger number of available adsorption sites [71]. Maximum $\mathrm{SO}_{4}{ }^{2-}$ sorption capacities of Ba-BFS-GP were $159.1 \mathrm{mg} \mathrm{g}^{-1}$ (74.5\% removal) and $99.0 \mathrm{mg} \mathrm{g}^{-1}$ (58.0\% removal) 58 in model $\mathrm{SO}_{4}{ }^{2-}$ solution and mine effluent, respectively. 
Figure 7. Effect of contact time on the removal efficiency of $\mathrm{SO}_{4}{ }^{2-}$ onto Ba-BFS-GP. o: $\mathrm{Model}_{\mathrm{SO}_{4}}{ }^{2-}$ solution $\left(\mathrm{C}_{0}, \mathrm{SO}_{4}{ }^{2-}: 1100 \mathrm{mg} \mathrm{L}{ }^{-1}\right), \square$ : Mine effluent $\left(\mathrm{C}_{0}, \mathrm{SO}_{4}{ }^{2-}: 853 \mathrm{mg} \mathrm{L}^{-1}\right)$. Initial $\mathrm{pH}: 7-8$, sorbent dosage: $5 \mathrm{~g} \mathrm{~L}^{-1}$, temperature: $22-23^{\circ} \mathrm{C}$.

\subsection{Kinetic modelling}

The pseudo-first-order, pseudo-second-order and Elovich kinetic models were used to evaluate the experimental data. The results are shown in Fig. 8, and the corresponding kinetic parameters are listed in Table 6. The best fit was observed with the pseudo-second-order kinetic model. Theoretical $q_{e, \text { cal }}$ values of the pseudo-second-order kinetic model agree well with the experimental uptake values.

Figure 8. a) Pseudo-first-order kinetic, b) pseudo-second-order kinetic and c) Elovich model plots of $\mathrm{SO}_{4}{ }^{2-}$ sorption on Ba-BFS-GP. o: Model $\mathrm{SO}_{4}{ }^{2-}$ solution $\left(\mathrm{C}_{0}, \mathrm{SO}_{4}{ }^{2-}: 1100 \mathrm{mg} \mathrm{L}{ }^{-1}\right), \square$ : Mine effluent $\left(\mathrm{C}_{0}\right.$, $\mathrm{SO}_{4}{ }^{2-}: 853 \mathrm{mg} \mathrm{L}^{-1}$ ). Initial $\mathrm{pH}: 7-8$, sorbent dosage: $5 \mathrm{~g} \mathrm{~L}^{-1}$, contact time: $24 \mathrm{~h}$, temperature: $22-23^{\circ} \mathrm{C}$. 
Table 6. Pseudo-first-order, pseudo-second-order and Elovich model parameters for Ba-BFS-GP in $\mathrm{SO}_{4}{ }^{2-}$ removal.

\begin{tabular}{|c|c|c|c|c|}
\hline \multicolumn{5}{|c|}{ Pseudo-first-order model } \\
\hline $\begin{array}{l}\mathrm{C}_{0} \\
\left(\mathrm{mg} \mathrm{L}^{-1}\right)\end{array}$ & $\begin{array}{c}q_{e, \exp } \\
\left(m g g^{-1}\right)\end{array}$ & $\begin{array}{c}q_{e, c a l c} \\
\left(\mathrm{mg} \mathrm{g}^{-1}\right)\end{array}$ & $\begin{array}{c}k_{1} \\
\left(\min ^{-1}\right)\end{array}$ & $\mathrm{R}^{2}$ \\
\hline 1100 & 159.08 & 40.51 & 0.0108 & 0.9776 \\
\hline 853 & 99.0 & 56.65 & 0.0085 & 0.9643 \\
\hline \multicolumn{5}{|c|}{ Pseudo-second-order } \\
\hline $\begin{array}{l}\mathrm{C}_{0} \\
\left(\mathrm{mg} \mathrm{L}^{-1}\right)\end{array}$ & $\begin{array}{c}q_{e, \exp } \\
\left(m g g^{-1}\right)\end{array}$ & $\begin{array}{c}q_{\text {calc }} \\
\left(\mathrm{mg} \mathrm{g}^{-1}\right)\end{array}$ & $\begin{array}{c}\mathrm{k}_{2} \\
\left(\mathrm{~g} \mathrm{mg}^{-1} \min ^{-1}\right)\end{array}$ & $\mathrm{R}^{2}$ \\
\hline 1100 & 159.08 & 158.73 & 2.217E-03 & 1 \\
\hline 853 & 99.0 & 100 & 7.6E-04 & 0.9994 \\
\hline \multicolumn{5}{|c|}{ Elovich model } \\
\hline $\begin{array}{l}\mathrm{C}_{0} \\
\left(\mathrm{mg} \mathrm{L}^{-1}\right)\end{array}$ & $\begin{array}{c}q_{e, \exp } \\
\left(\mathrm{mg} \mathrm{g}^{-1}\right)\end{array}$ & $\begin{array}{c}b \\
\left(g^{-1}\right)\end{array}$ & $\begin{array}{c}\mathrm{U}_{0} \\
\left(\mathrm{mg} \mathrm{g}^{-1} \min ^{-1}\right)\end{array}$ & $\mathrm{R}^{2}$ \\
\hline 1100 & 159.08 & 0.1633 & $1 E+09$ & 0.9214 \\
\hline 853 & 99.0 & 0.1037 & 224.175 & 0.8826 \\
\hline
\end{tabular}

\subsection{Weber and Morris intraparticle diffusion model}

The Weber and Morris intraparticle diffusion model was applied to the kinetic data of Ba-BFS-GP against the $\mathrm{SO}_{4}{ }^{2-}$ (Fig. 9). If a plot of $q_{t}$ versus $t^{1 / 2}$ presents a straight line from the origin, the ratelimiting step in the sorption mechanism is diffusion from the outer surface into the pores of the material. The data of $\mathrm{SO}_{4}{ }^{2-}$ sorption on Ba-BFS-GP shows two plots, which do not pass through the origin. This indicates that intraparticle diffusion is not the rate-limiting step. The first stage can be attributed to the instantaneous or external surface sorption while the second stage is the low diffusion of adsorbate from the surface to the inner pore [62].

Figure 9. Weber and Morris intraparticle diffusion model plot of $\mathrm{SO}_{4}{ }^{2-}$ sorption on Ba-BFS-GP. O: Model $\mathrm{SO}_{4}{ }^{2-}$ solution $\left(\mathrm{C}_{0}, \mathrm{SO}_{4}{ }^{2-}: 1100 \mathrm{mg} \mathrm{L}^{-1}\right)$, $\square$ : Mine effluent $\left(\mathrm{C}_{0}, \mathrm{SO}_{4}{ }^{2-}: 853 \mathrm{mg} \mathrm{L}^{-1}\right)$. Initial $\mathrm{pH}: 7-8$, sorbent dosage: $5 \mathrm{~g} \mathrm{~L}^{-1}$, contact time: $24 \mathrm{~h}$, temperature: $22-23^{\circ} \mathrm{C}$. 


\subsection{Thermodynamic parameters}

Standard enthalpy $(\Delta H)$ and entropy $(\Delta S)$ were obtained from the slope and intercept of the plot of In $K_{c}$ vs. $1 / T$, as shown in Fig. 10 and listed in Table 7 . The negative value of $\Delta G$ indicated that the sorption process is spontaneous in nature. Affinity of the Ba-BFS-GP for $\mathrm{SO}_{4}{ }^{2-}$ is represented by the positive value of $\Delta S$, which indicated that the sorption process increased the entropy at the solid/solution interface during the sorption process. The positive value of $\Delta H$ suggested that the interaction of $\mathrm{SO}_{4}{ }^{2-}$ and $\mathrm{Ba}-\mathrm{BFS}-\mathrm{GP}$ is endothermic in nature. The $\Delta H$ obtained from thermodynamic calculations $\left(\leq 40 \mathrm{~kJ} \mathrm{~mol}^{-1}\right)$ suggests a physisorption process involving weak interactions. [10, 62, 66, 72-74]

Figure 10. Van't Hoff plot for adsorption of $\mathrm{SO}_{4}{ }^{2-}$ removal. Initial $\mathrm{pH}: 7-8$, adsorbent dosage: $5 \mathrm{~g} \mathrm{~L}^{-1}$, $\mathrm{C}_{0}\left(\mathrm{SO}_{4}{ }^{2-}\right): 1200 \mathrm{mg} \mathrm{L}^{-1}$.

Table 7. Thermodynamics parameters for the sorption of $\mathrm{SO}_{4}{ }^{2-}$ on Ba-BFS-GP at different temperatures.

\begin{tabular}{lccc}
\hline Temperature $\left({ }^{\circ} \mathrm{C}\right)$ & $\Delta \mathrm{G}\left(\mathrm{kJ} \mathrm{mol}{ }^{-1}\right)$ & $\Delta \mathrm{S}\left(\mathrm{J} \mathrm{mol}^{-1} \mathrm{~K}^{-1}\right)$ & $\Delta \mathrm{H}\left(\mathrm{kJ} \mathrm{mol}{ }^{-1}\right)$ \\
\hline 10 & -10.354 & & \\
22 & -11.389 & 56.598 & \\
40 & -12.059 & & \\
\hline
\end{tabular}

\subsection{Column studies}

Column studies (Fig. 11) have been carried out for Ba-BFS-GP as a sorbent in order to study its sorption capacity in dynamic conditions. Flow rates of 0.24 and $0.85 \mathrm{~L} \mathrm{~h}^{-1}$ were used for the breakthrough simulation. Initially, total $\mathrm{SO}_{4}{ }^{2-}$ removal was observed with a lower flow rate. However, the removal of $\mathrm{SO}_{4}{ }^{2-}$ starts to linearly decrease after $40 \mathrm{~min}$ (corresponding to $0.16 \mathrm{~L}$ of treated effluent) and drops below $50 \%$ after 140 min (corresponding to $0.56 \mathrm{~L}$ of treated effluent). Therefore, it could be estimated that $18.7 \mathrm{~m}^{3}$ of mine effluent with a similar composition could be treated with $1 \mathrm{t}$ of $\mathrm{Ba}$ - 
BFS-GP with over $50 \% \mathrm{SO}_{4}{ }^{2-}$ removal. After use, Ba-BFS-GP could be further utilised in selective radium adsorption from contaminated waters due to accumulation of $\mathrm{BaSO}_{4}$ as indicated by Kunze et al. [75]

\subsection{Barium leaching}

The leaching of Ba from Ba-BFS-GP was studied in mine effluent and distilled water at initial $\mathrm{pH}$ values of 2 and 8. The results indicate that dissolved $\mathrm{Ba}^{2+}$ concentrations from Ba-BFS-GP were 600 and 32 $\mathrm{mg} \mathrm{L}^{-1}$ at initial $\mathrm{pH}$ values 2 and 8 in distilled water. However, in the case of mine effluent $\left(\mathrm{C}_{0}\left(\mathrm{SO}_{4}{ }^{-2}\right)\right.$ : 850-870 $\mathrm{mg} \mathrm{L}^{-1}$ ), the dissolved $\mathrm{Ba}^{2+}$ concentrations were 0.175 and $0.375 \mathrm{mg} \mathrm{L}^{-1}$ at initial $\mathrm{pH}$ values 2 and 8 , respectively. Clearly lower concentrations of dissolved $\mathrm{Ba}$ in mine effluent are due to the instantaneous precipitation of low solubility $\mathrm{BaSO}_{4}$. The limit for $\mathrm{Ba}$ content in domestic water is 0.7 $\mathrm{mg} \mathrm{L}^{-1}[76]$, so it would be safe to utilise Ba-BFS-GP for treating industrial wastewater containing $\mathrm{SO}_{4}{ }^{2-}$.

\subsection{Sorption mechanism}

The sorption mechanism of geopolymers in the removal of cations from aqueous solutions has been suggested to be cation exchange [31, 44, 77]. However, geopolymers have low affinity towards sorption of anions due to negative zeta potential [46]. In the present work, geopolymers were converted into Ba-form by a cation-exchange process and further applied for $\mathrm{SO}_{4}{ }^{2-}$ removal. The probable removal mechanism of $\mathrm{SO}_{4}{ }^{2-}$ is based on the surface complexation or precipitation of extremely low solubility $\mathrm{BaSO}_{4}\left(\mathrm{~K}_{\mathrm{sp}}=1.08 * 10^{-10}\right.$ at $25^{\circ} \mathrm{C}$, solubility $\left.0.0031 \mathrm{~g} \mathrm{~L}^{-1}, 20^{\circ} \mathrm{C}\right)[50,78]$. Due to the low solubility, $\mathrm{BaSO}_{4}$ is considered non-toxic. However, the removal of sulphate with the direct precipitation as $\mathrm{BaSO}_{4}$ is not recommended due to generation of secondary waste in the form of sludge [14]. The presence of $\mathrm{BaSO}_{4}$ was confirmed with XRD from a used sorbent material. 


\section{Conclusions}

Ba-modified blast-furnace-slag and Ba-modified metakaolin with and without a geopolymerisation step were studied for $\mathrm{SO}_{4}{ }^{2-}$ removal. Ba-modified geopolymerised materials exhibit higher $\mathrm{SO}_{4}{ }^{2-}$ ion removal capacity than Ba-modified materials without a geopolymerisation step. This is explained by the cation exchange process $\left(\mathrm{Na}^{+}\right.$is replaced by $\left.\mathrm{Ba}^{2+}\right)$ taking place in the geopolymer framework structure during Ba-modification. The best sorbent material for $\mathrm{SO}_{4}{ }^{2-}$ removal was Ba-BFS-GP. The optimum $\mathrm{pH}$ required for maximum sorption was found to be $7-8$. The maximum experimental sorption capacities were 91.1 and $119.0 \mathrm{mg} \mathrm{g}^{-1}$ for synthetic model solution and mine effluent, respectively. Sorption capacities found in this study were among the highest of reported in the literature. The Sips isotherm model described the sorption well. Sorption kinetics followed the pseudo-second-order kinetic model, and the Weber and Morris intraparticle diffusion model showed that the sorption mechanism included two different steps. The positive enthalpy value indicates that the adsorption process was endothermic in nature. The results from the present study indicate that Ba-BFS-GP could be a technically feasible $\mathrm{SO}_{4}{ }^{2-}$ sorbent for wastewater treatment (e.g. in the mining industry) especially for applications in which very low $\mathrm{SO}_{4}{ }^{2-}$ levels are desired.

\section{Acknowledgments}

This study was conducted as a part of SULKA (A32164, 524/2012) and GeoSorbents (Tekes, project 4684/31/2014) projects. Maa- ja vesitekniikan tuki ry. is gratefully acknowledged for funding this study. The authors would like to thank MSc Sara Lopéz and BSc Riikka Juhola for their contribution in some laboratory experiments and Mr. Jaakko Pulkkinen and Mr. Tuomo Vähätiitto for their assistance in $\mathrm{SO}_{4}{ }^{2-}$ and metal analysis. 


\section{References}

[1] W. Cao, Z. Dang, X. Zhou, X. Yi, P. Wu, N. Zhu, G. Lu, Removal of sulphate from aqueous solution using modified rice straw: Preparation, characterization and adsorption performance, Carbohydr. Polym. 85 (2011) 571-577.

[2] A.M. Silva, R.M.F. Lima, V.A. Leão, Mine water treatment with limestone for sulfate removal, J. Hazard. Mater. 221-222 (2012) 45-55.

[3] D. Rui, L. Yuanfa, W. Xingguo, H. Jianhua, Adsorption of sulfate ions from aqueous solution by surfactant-modified palygorskite, J. Chem. Eng. Data. 56 (2011) 3890-3896.

[4] N. Priyantha, S. Perera, Removal of sulfate, phosphate and colored substances in wastewater effluents using feldspar, Water Res. Manage. 14 (2000) 417-433.

[5] Finlex, Ministry of Social Affairs and Health, 1352/2015 Sosiaali- ja terveysministeriön asetus talousveden laatuvaatimuksista ja valvontatutkimuksista (In Finnish), http://www.finlex.fi, 2015 (accessed 01.12.15).

[6] C. Namasivayam, M.V. Sureshkumar, Removal of sulfate from water and wastewater by surfactantmodified coir pith, an agricultural solid "waste" by adsorption methodology, J. Env. Eng. Manage. 17 (2007) 129-135.

[7] INAP, Treatment of sulphate in mine effluents, International network for acid prevention. Available

from http://www.inap.com.au/public_downloads/Research_Projects/Treatment_of_Sulphate_in_Min e_Effluents_-_Lorax_Report.pdf, 2003 (accessed 01.12.15).

[8] L. Hartinger, Handbook of effluent treatment and recycling for the metal finishing industry, 2. ed., ASM International, Novelty, OH, USA, 1994.

[9] A.J. Geldenhuys, J.P. Maree, M. de Beer, P. Hlabela, An integrated limestone/lime process for partial sulphate removal, J. S. Afr. Inst. Min. Metall. 103 (2003) 345-354.

[10] R. Katal, M.S. Baei, H.T. Rahmati, H. Esfandian, Kinetic, isotherm and thermodynamic study of nitrate adsorption from aqueous solution using modified rice husk, J. Ind. Eng. Chem. 18 (2012) 295-302.

[11] P. Sang, Y. Wang, L. Zhang, L. Chai, H. Wang, Effective adsorption of sulfate ions with poly(mphenylenediamine) in aqueous solution and its adsorption mechanism, Transactions of Nonferrous Metals Society of China. 23 (2013) 243-252. 
[12] A.C.A. de Lima, R.F. Nascimento, F.F. de Sousa, J.M. Filho, A.C. Oliveira, Modified coconut shell fibers: A green and economical sorbent for the removal of anions from aqueous solutions, Chem. Eng. J. 185-186 (2012) 274-284.

[13] M.S. Salman, Removal of sulfate from waste water by activated carbon, Al-Khwarizmi Eng. J. 5 (2009) 72-76.

[14] N. Koshy, D.N. Singh, Fly ash zeolites for water treatment applications. J. Environ. Chem. Eng. 4 (2016) 1460-1472.

[15] E. lakovleva, E. Mäkilä, J. Salonen, M. Sitarz, M. Sillanpää, Industrial products and wastes as adsorbents for sulphate and chloride removal from synthetic alkaline solution and mine process water. Chem. Eng. J. 259 (2015) 364-371.

[16] R. Juang, W. Wu, Adsorption of sulfate and copper(II) on goethite in relation to the changes of zeta potentials, J. Colloid Interface Sci. 249 (2002) 22-29.

[17] P. Roonasi, A. Holmgren, An ATR-FTIR study of sulphate sorption on magnetite; rate of adsorption, surface speciation, and effect of calcium ions, J. Colloid Interface Sci. 333 (2009) 27-32.

[18] R.P.J.J. Rietra, T. Hiemstra, W.H. van Riemsdijk, Comparison of selenate and sulfate adsorption on goethite, J. Colloid Interface Sci. 240 (2001) 384-390.

[19] A.M. Jubb, D. Verreault, R. Posner, L.J. Criscenti, L.E. Katz, H.C. Allen, Sulfate adsorption at the buried hematite/solution interface investigated using total internal reflection (TIR)-Raman spectroscopy, J. Colloid Interface Sci. 400 (2013) 140-146.

[20] A.D. Vujaković, M.R. Tomašević-Čanović, A.S. Daković, V.T. Dondur, The adsorption of sulphate, hydrogenchromate and dihydrogenphosphate anions on surfactant-modified clinoptilolite, Appl. Clay. Sci. 17 (2000) 265-277.

[21] C.R. Oliveira, J. Rubio, New basis for adsorption of ionic pollutants onto modified zeolites, Min. Eng. 20 (2007) 552-558.

[22] R. Katal, M. Vafaie Sefti, M. Jafari, A.H. Saeedi Dehaghani, S. Sharifian, M.A. Ghayyem, Study effect of different parameters on the sulphate sorption onto nano alumina, J. Ind. Eng. Chem. 18 (2012) 230-236.

[23] T. Delfosse, P. Delmelle, B. Delvaux, Sulphate sorption at high equilibrium concentration in Andosols, Geoderma. 136 (2006) 716-722. 
[24] F. Bazer-Bachi, M. Descostes, E. Tevissen, P. Meier, B. Grenut, M.-. Simonnot, M. Sardin, Characterization of sulphate sorption on Callovo-Oxfordian argillites by batch, column and throughdiffusion experiments, Physics and Chemistry of the Earth, Parts A/B/C. 32 (2007) 552-558.

[25] J.P. Gustafsson, M. Akram, C. Tiberg, Predicting sulphate adsorption/desorption in forest soils: Evaluation of an extended Freundlich equation, Chemosphere. 119 (2015) 83-89.

[26] V.F.F. Barbosa, K.J.D. MacKenzie, C. Thaumaturgo, Synthesis and characterisation of materials based on inorganic polymers of alumina and silica: sodium polysialate polymers, Int. J. Inorg. Mat. 2 (2000) 309-317.

[27] S.V. Dimitrova, D.R. Mehanjiev, Interaction of blast-furnace slag with heavy metal ions in water solutions, Wat. Res. 34 (2000) 1957-1961.

[28] P. Duxson, A. Fernández-Jiménez, J. L. Provis, G. C. Lukey, A. Palomo, J.S.J. van Deventer, Geopolymer technology: the current state of the art, J. Mater. Sci. (2007) 42:2917-2933.

[29] L. Li, S. Wang, Z. Zhu, Geopolymeric adsorbents from fly ash for dye removal from aqueous solution, J. Colloid Interface Sci. 300 (2006) 52-59.

[30] Q. Tang, Y. Ge, K. Wang, Y. He, X. Cui, Preparation and characterization of porous metakaolinbased inorganic polymer spheres as an adsorbent, Mater Des. 88 (2015) 1244-1249.

[31] S.J. O'Connor, K.J.D. MacKenzie, M.E. Smith, J.V. Hanna, lon exchange in the charge-balancing sites of aluminosilicate inorganic polymers, J. Mater. Chem. 20 (2010) 10234-10240.

[32] F.J. López, S. Sugita, M. Tagaya, T. Kobayashi, Metakaolin-based geopolymers for targeted adsorbents to heavy metal ion separation. J. Mat. Sci. Chem. Eng. 2 (2014) 16-27.

[33] T.W. Cheng, M.L. Lee, M.S. Ko, T.H. Ueng, S.F. Yang, The heavy metal adsorption characteristics on metakaolin-based geopolymer, Appl. Clay. Sci. 56 (2012) 90-96.

[34] Y.J. Zhang, L.C. Liu, L.L. Ni, B.L. Wang, A facile and low-cost synthesis of granulated blast furnace slag-based cementitious material coupled with $\mathrm{Fe}_{2} \mathrm{O}_{3}$ catalyst for treatment of dye wastewater, Applied Catalysis B: Environmental. 138-139 (2013) 9-16.

[35] K. Al-Zboon, M.S. Al-Harahsheh, F.B. Hani, Fly ash-based geopolymer for Pb removal from aqueous solution, J. Hazard. Mater. 188 (2011) 414-421.

[36] C.K. Geethamani, S.T. Ramesh, R. Gandhimathi, P.V. Nidheesh, Alkali-treated fly ash for the removal of fluoride from aqueous solutions, Desalination and Water Treatment. 52 (2014) 3466-3476. 
[37] N. Koshy, D.N. Singh, B. Jha, S. Kadali, J. Patil, Characterization of Na and Ca zeolites synthesized by various hydrothermal treatments of fly ash. Adv. Civil Eng. Mat. ASTM International. 4 (2015) 131143.

[38] S. Wang, L. Li, Z.H. Zhu, Solid-state conversion of fly ash to effective adsorbents for Cu removal from wastewater, J. Hazard. Mater. 139 (2007) 254-259

[39] S. Andrejkovičová, A. Sudagar, J. Rocha, C. Patinha, W. Hajjaji, E. Ferreira da Silva, A. Velosa, F. Rocha, The effect of natural zeolite on microstructure, mechanical and heavy metals adsorption properties of metakaolin based geopolymers, Appl. Clay Sci. 126 (2016) 141-152.

[40] G. Gong, S. Ye, Y. Tian, Q. Wang, J. Ni, Y. Chen, Preparation of a new sorbent with hydrated lime and blast furnace slag for phosphorus removal from aqueous solution, J. Haz. Mat. 166 (2009) 714719.

[41] J. Davidovits, Geopolymers: inorganic polymeric new materials, J. Therm. Anal. 37 (1991) 1633-1656.

[42] J. Davidovits, Geopolymers and geopolymeric new material, J. Thermal. Anal. 35 (1998) 429-441.

[43] R.I. Yousef, B. El-Eswed, M. Alshaaer, F. Khalili, H. Khoury, The influence of using Jordanian natural zeolite on the adsorption, physical, and mechanical properties of geopolymers products, J. Hazard. Mater. 165 (2009) 379-387.

[44] T. Luukkonen, H. Runtti, M. Niskanen, E. Tolonen, M. Sarkkinen, K. Kemppainen, J. Rämö, U. Lassi, Simultaneous removal of $\mathrm{Ni}(\mathrm{II}), \mathrm{As}(\mathrm{III})$, and $\mathrm{Sb}(\mathrm{III})$ from spiked mine effluent with metakaolin and blast-furnace-slag geopolymers, J. Environ. Manage. 166 (2016) 579-588.

[45] T.W. Chen, M.L. Lee, M.S. Ko, T.H. Ueng, S.F. Yang, The heavy metal adsorption characteristics on metakaolin-based geopolymer, Appl. Clay. Sci. 56 (2012) 90-96.

[46] T. Luukkonen, M. Sarkkinen, K. Kemppainen, J. Rämö, U. Lassi, Metakaolin geopolymer characterization and application for ammonium removal from model solutions and landfill leachate, Appl. Clay. Sci. 119, Part 2 (2016) 266-276.

[47] Š. C. Stefanović, N. Z. Logar, K. Margeta, N. N. Tušar, I. Arčon, K. Maver, J. Kovač, V. Kaučič, Structural investigation of $\mathrm{Zn}^{2+}$ sorption on clinoptilolite tuff from the Vranjska Banja deposit in Serbia, Micropor. Mesopor. Mater. 105 (2007) 251-259.

[48] C.R. Oliveira, J. Rubio, New basis for adsorption of ionic pollutants onto modified zeolites, Min. Eng. 20 (2007) 552-558. 
[49] M. Šiljeg, Š. C. Stefanović, M. Mazaj, N. N. Tušar, I. Arčon, J. Kovač, K. Margeta, V. Kaučič, N. Z. Logar, Structure investigation of $\mathrm{As}(\mathrm{III})$ - and $\mathrm{As}(\mathrm{V})$-species bound to Fe-modified clinoptilolite tuffs, Micropor. Mesopor. Mat. 118 (2009) 408-415.

[50] K. Margeta, N. Z. Logar, M. Šiljeg, A. Farkaš, Natural zeolites in water treatment - How effective is their use, http://dx.doi.org/10.5772/50738

[51] D. Graham, The characterization of physical adsorption systems. I. The equilibrium function and standard free energy of adsorption, J. Phys. Chem. 57 (1953) 665-669.

[52] R. Sips, On the structure of a catalyst surface, J. Chem. Phys. 16 (1948) 490-495.

[53] O. Redlich, DL Peterson, A useful adsorption isotherm. J. Phys. Chem. 63 (1959) 1024-1024.

[54] J. Toth, State equations of the solid gas interface layer, Acta Chem. Acad. Hung. 69 (1971) 311-328.

[55] S. Lagergren, About the theory of so-called adsorption of soluble substances., K. Sven. Vetenskapsakad. Handl. 24 (1898) 1-39.

[56] Y.S. Ho, G. McKay, Pseudo-second order model for sorption processes, Process Biochemistry. 34 (1999) 451-465.

[57] J. Zeldowitsch, Über den mechanismus der katalytischen oxydation von $\mathrm{CO}$ an $\mathrm{MnO}_{2}$ [About the mechanism of catalytic oxidation of $\mathrm{CO}$ over $\mathrm{MnO}_{2}$ ], Acta Physicochim. URSS. 1 (1934) 364-449.

[58] W.J. Weber Jr., J.C. Morris, Kinetics of adsorption of carbon from solution, J. Sanit. Eng. Div. Am. Soc. Civ. Eng. 89 (1963) 31-60.

[59] M.A. Karakassides, D. Gournis, D. Petridis, An infrared reflectance study of Si-O vibrations in thermally treated alkali-saturated montmorillonates, Clay Minerals. 38 (1999) 429-438.

[60] C.O. Arean, G.F. Bibiloni, M.R. Delgado, FT-IR spectroscopic and thermodynamic study on the adsorption of carbon dioxide and dinitrogen in the alkaline zeolite K-L, Appl. Surf. Sci. 259 (2012) 367-370.

[61] K. Tan, S. Zuluaga, Q. Gong, Y. Gao, N. Nijem, J. Li, T. Thonhauser, Y.J. Chabal, Competitive coadsorption of $\mathrm{CO}_{2}$ with $\mathrm{H}_{2} \mathrm{O}, \mathrm{NH}_{3}, \mathrm{SO}_{2}, \mathrm{NO}, \mathrm{NO}_{2}, \mathrm{~N}_{2}, \mathrm{O}_{2}$, and $\mathrm{CH}_{4}$ in M-MOF-74 (M= Mg, Co, Ni): the role of hydrogen bonding,_Chem. Mater. 27 (2015) 2203-2217.

[62] A. Bhatnagar, E. Kumar, M. Sillanpää, Nitrate removal from water by nano-alumina: Characterization and sorption studies, Chem. Eng. J. 163 (2010) 317-323. 

sawdust, Bioresour. Technol. 96 (2005) 791-795.

[64] A. Shukla, Y. Zhang, P. Dubey, J.L. Margrave, S.S. Shukla, The role of sawdust in the removal of unwanted materials from water, J. Hazard. Mater. 95 (2002) 137-152.

[65] D.H. Lataye, I.M. Mishra, I.D. Mall, Adsorption of $\alpha$-picoline onto rice husk ash and granular activated carbon from aqueous solution: Equilibrium and thermodynamic study, Chem. Eng. J. 147 (2009) 139-149.

[66] N.Y. Mezenner, A. Bensmaili, Kinetics and thermodynamic study of phosphate adsorption on iron hydroxide-eggshell waste, Chem. Eng. J. 147 (2009) 87-96.

[67] W.D. Schecker, D.C. McAvoy, MINEQL+ a chemical equilibrium modelling system version 4.5 for windows. User's Manual. Environmental research software, 2003.

[68] C. Namasivayam, D. Sangeetha, Application of coconut coir pith for the removal of sulfate and other anions from water, Desalination. 219 (2008) 1-13.

[69] C. Wu, C. Kuo, C. Lin, S. Lo, Modeling competitive adsorption of molybdate, sulfate, selenate, and selenite using a Freundlich-type multi-component isotherm, Chemosphere. 47 (2002) 283-292.

[70] A. Moret, J. Rubio, Sulphate and molybdate ions uptake by chitin-based shrimp shells, Minerals Eng. 16 (2003) 715-722.

[71] E.-.Z. El-Ashtoukhy, N.K. Amin, O. Abdelwahab, Removal of lead (II) and copper (II) from aqueous solution using pomegranate peel as a new adsorbent, Desalination. 223 (2008) 162-173.

[72] A. Bhatnagar, A.K. Minocha, M. Sillanpää, Adsorptive removal of cobalt from aqueous solution by utilizing lemon peel as biosorbent, Biochem. Eng. J. 48 (2010) 181-186.

[73] H. Kalavathy, B. Karthik, L.R. Miranda, Removal and recovery of Ni and Zn from aqueous solution using activated carbon from Hevea brasiliensis: Batch and column studies, Colloids and Surfaces B: Biointerfaces. 78 (2010) 291-302.

[74] M.V. Subbaiah, Y.S. Yun, Biosorption of nickel(II) from aqueous solution by the fungal mat of trametes versicolor (Rainbow) biomass: equilibrium, kinetics, and thermodynamis studies, Biotechnol. Bioprocess Eng. 18 (2013) 280-288.

[75] C.E. Kunze, I. Hermann, I. Griebel, G. Kiessig, F. Dullies, M. Schreiter, Entwicklung und praxiseinsatz eines hocheffizienten selektiven sorbens fur radium [Development and practical application of a highly selective sorbent for radium. In German, GWF Wasser Abwasser. 143 (2002) Jg., no $7 / 8$. 
[76] WHO (2004) Barium in Drinking-water Background document for development of WHO Guidelines for Drinking-water Quality. WHO/SDE/WSH/03.04/76.

URI:http://www.who.int/water_sanitation_health/dwq/chemicals/barium.pdf. Cited 2016/02/01.

[77] T. Skorina, lon exchange in amorphous alkali-activated aluminosilicates: Potassium based geopolymers, Appl. Clay. Sci. 87 (2014) 205-211.

[78] D.R. Lide, CRC Handbook of Chemistry and Physics. 84. ed., CRC Press, 2003 


\section{Blast furnace} slag (gehlenite)

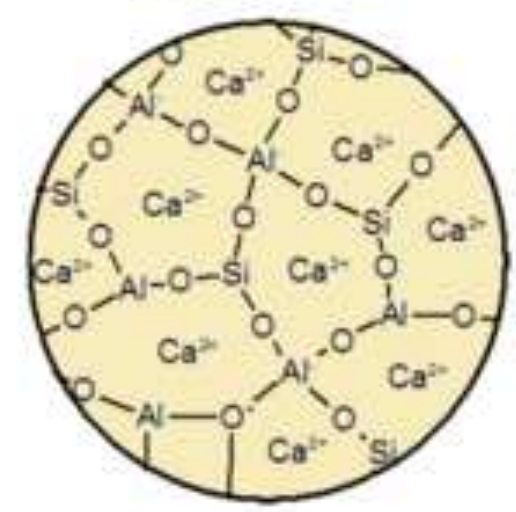

Sulphate removal capacity $\mathrm{q} \approx 0 \mathrm{mg} / \mathrm{g} \mathrm{SO}_{4}{ }^{2-}$
Blast-furnaceslag geopolymer

Alkali treatment / geopolymerisation

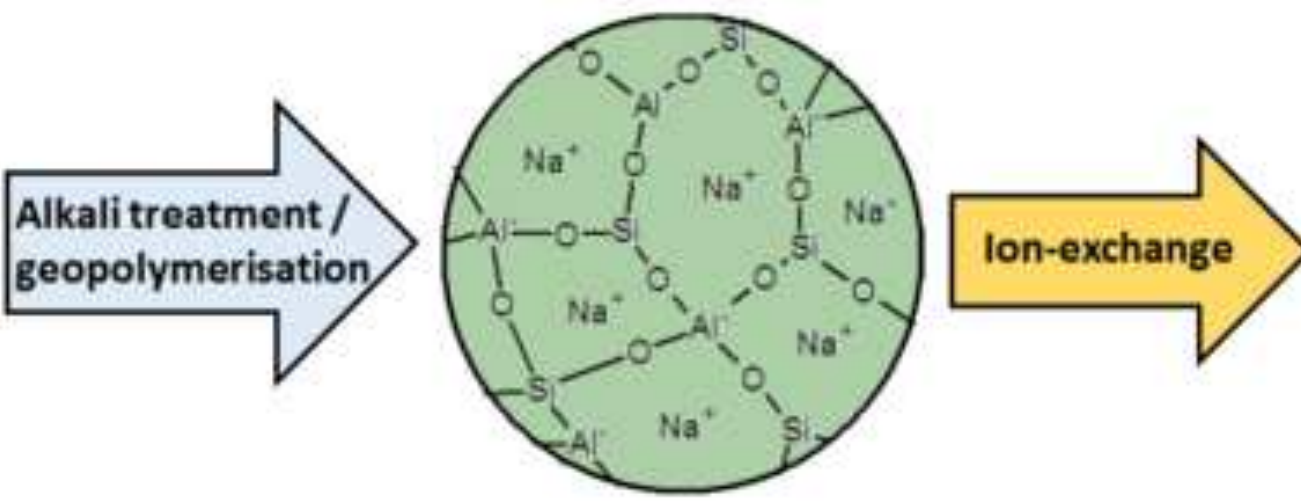

Sulphate removal capacity $q \approx 0 \mathrm{mg} / \mathrm{g} \mathrm{SO}{ }_{4}^{2-}$
Barium-modified blast-furnace-slag geopolymer

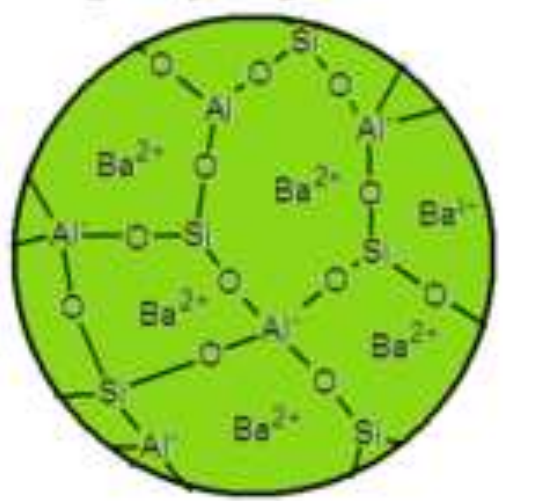

Sulphate removal capacity $q \approx 119 \mathrm{mg} / \mathrm{g} \mathrm{SO}_{4}{ }^{2-}$ 
Click here to download high resolution image

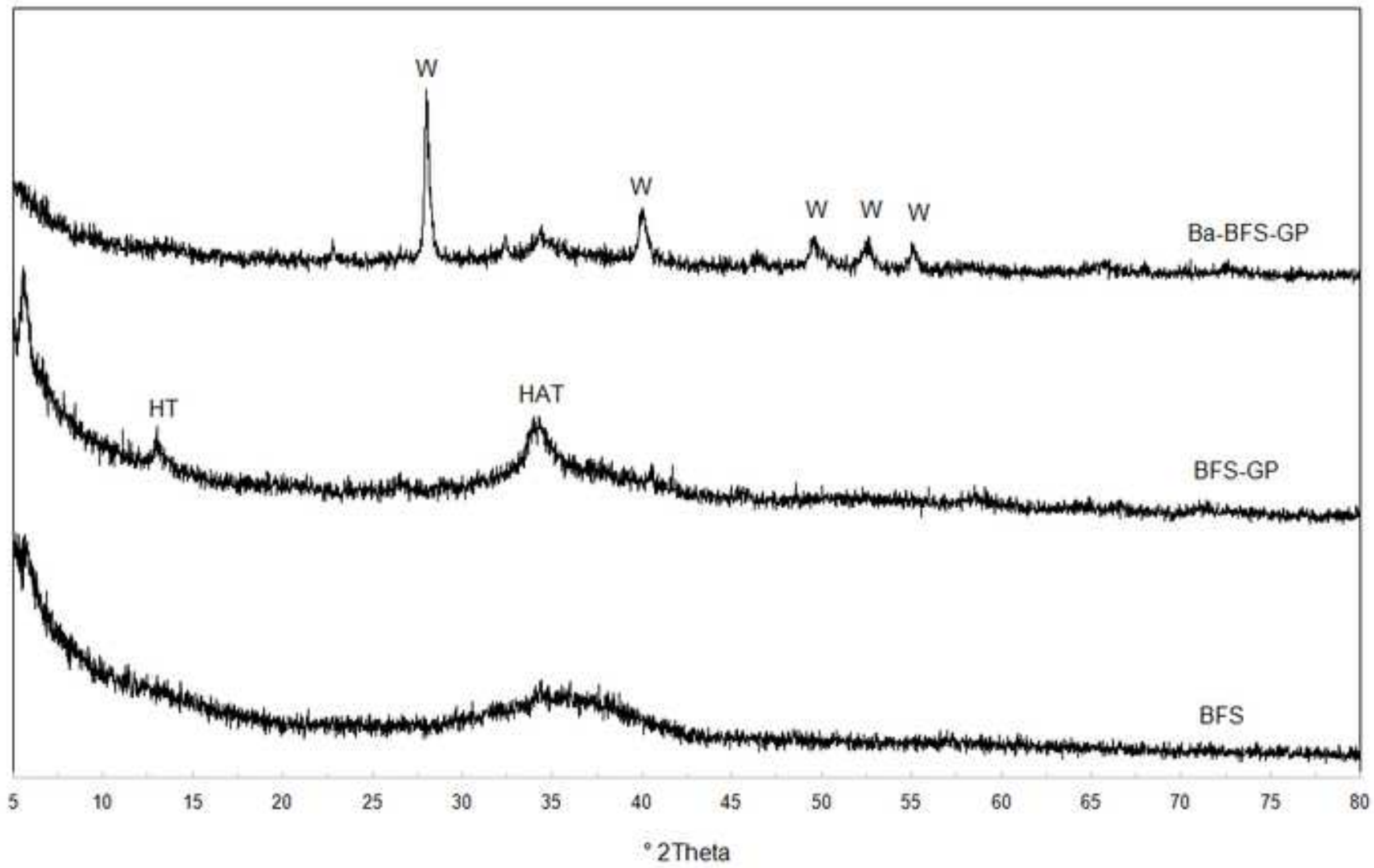


Click here to download high resolution image

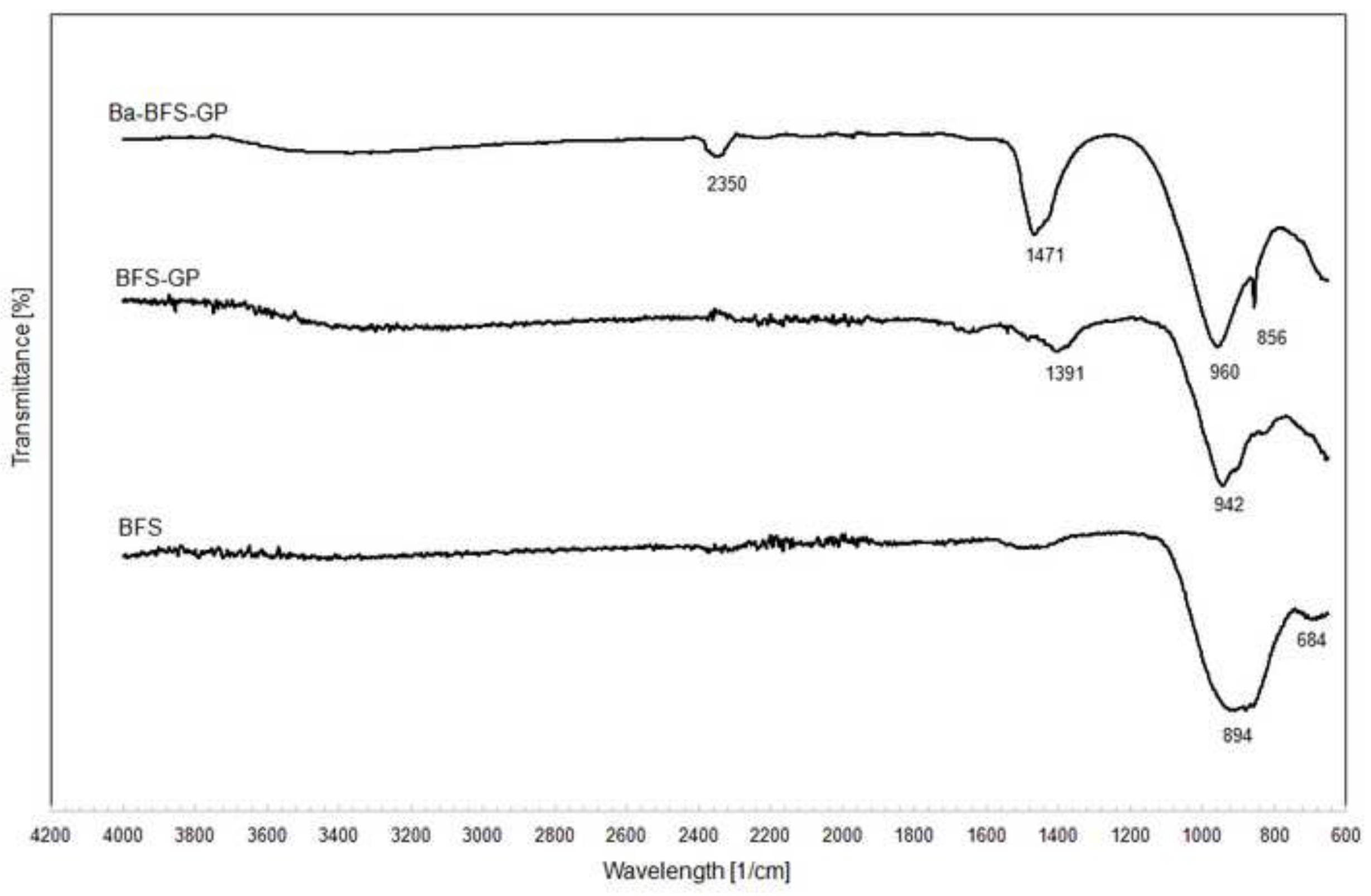


Click here to download high resolution image

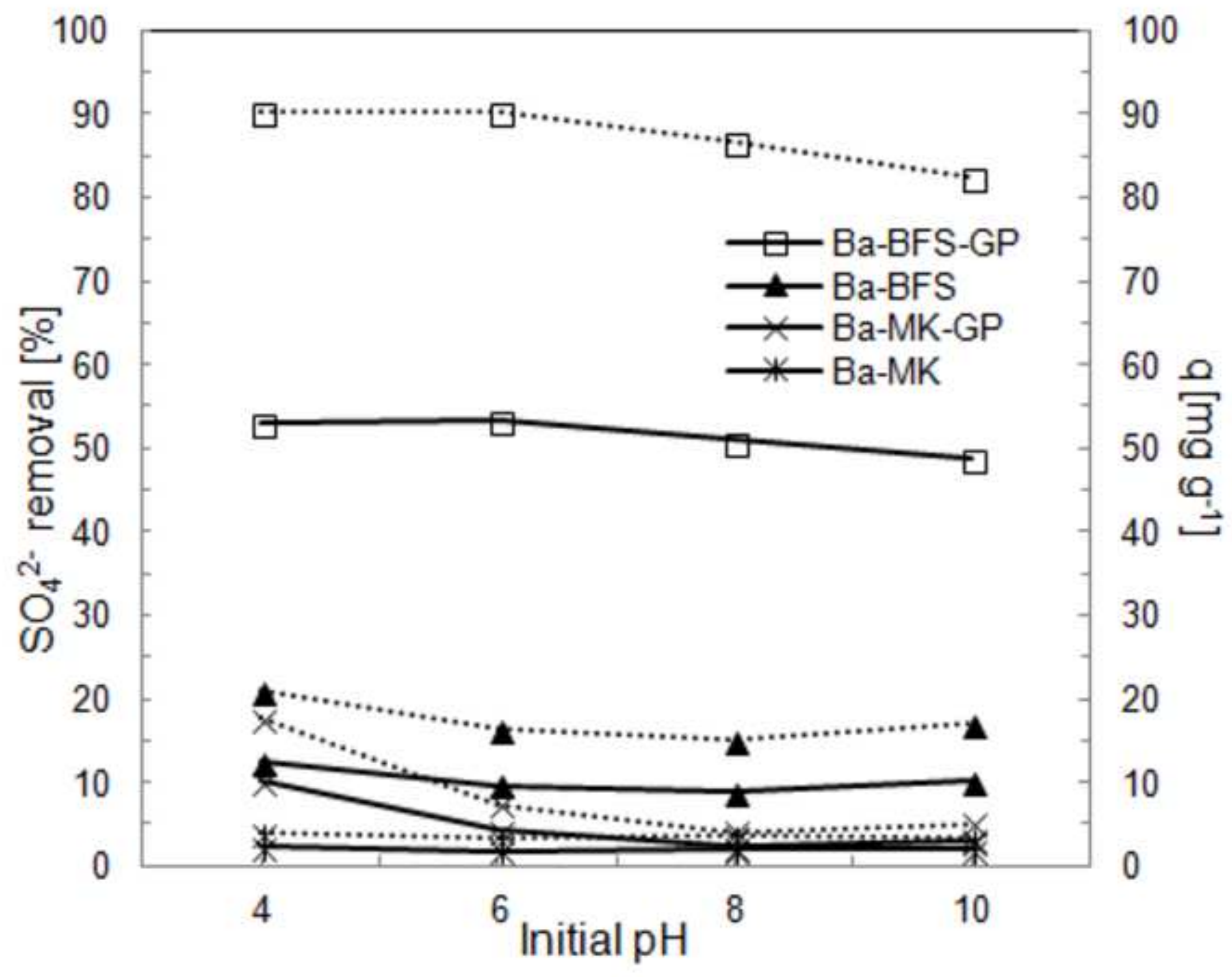

Click here to download high resolution image 
Click here to download high resolution image

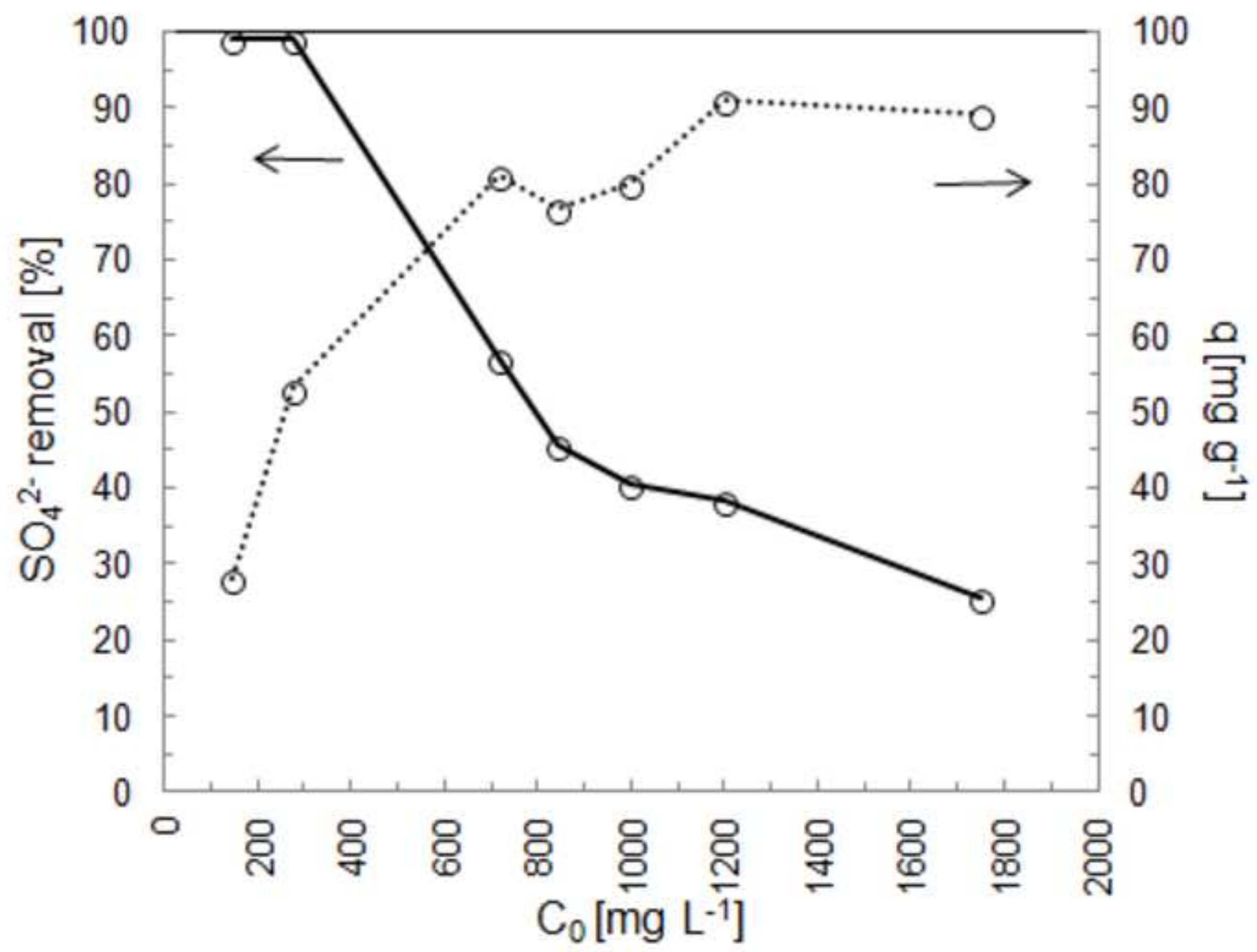


Click here to download high resolution image
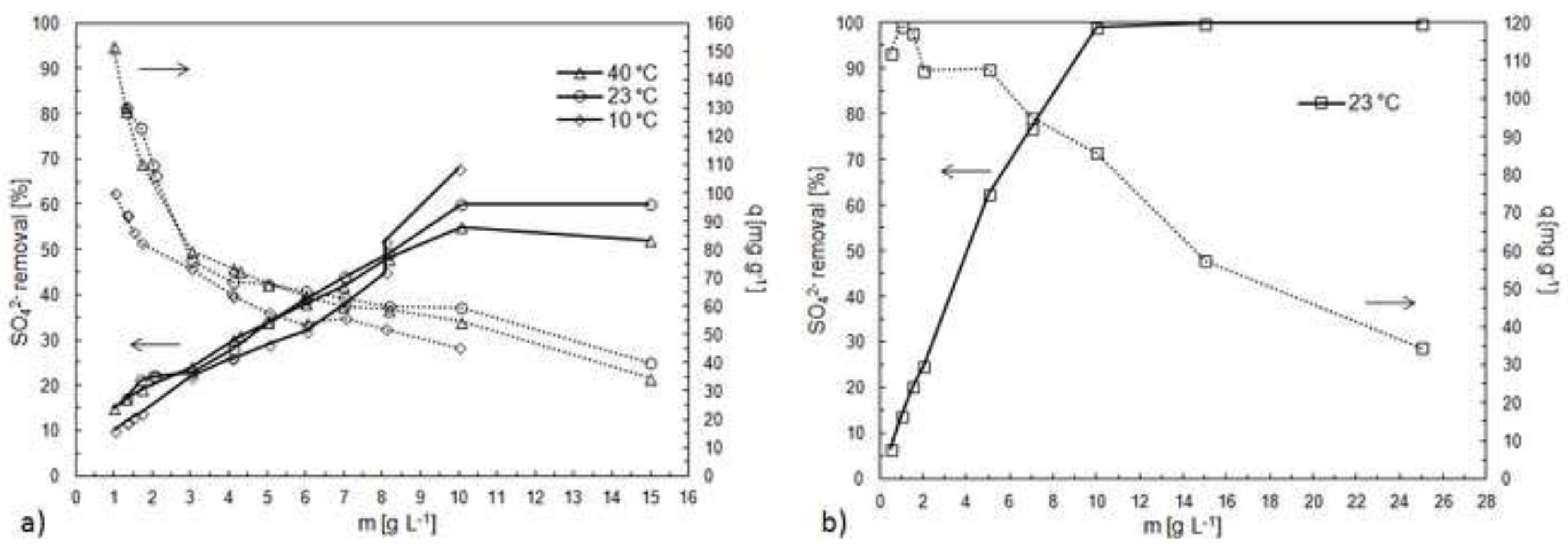

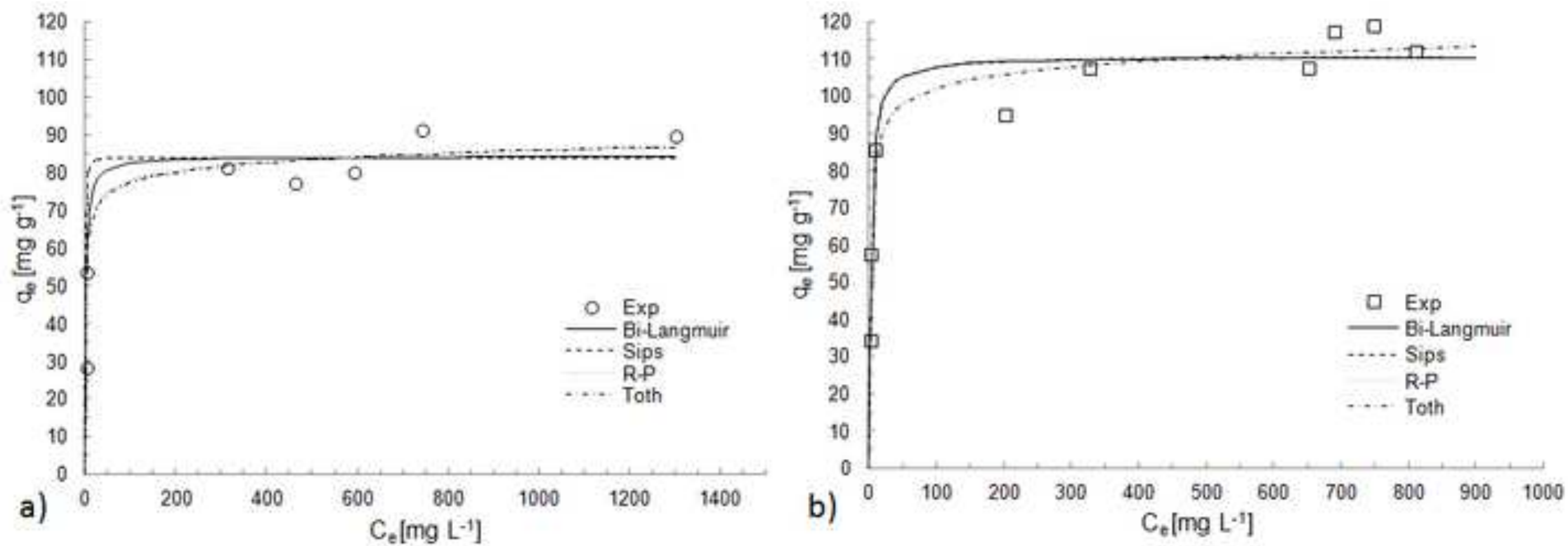


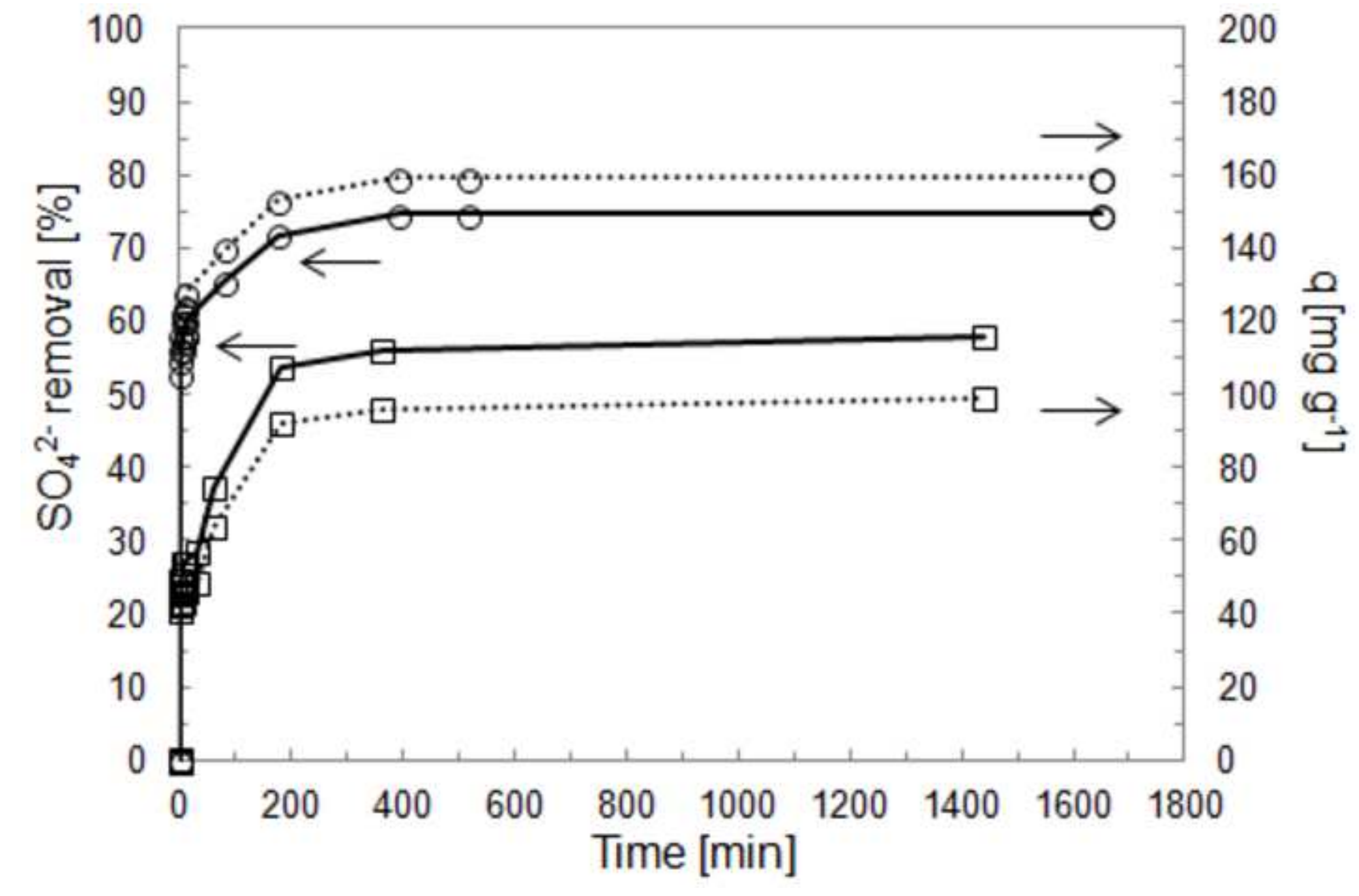


Click here to download high resolution image
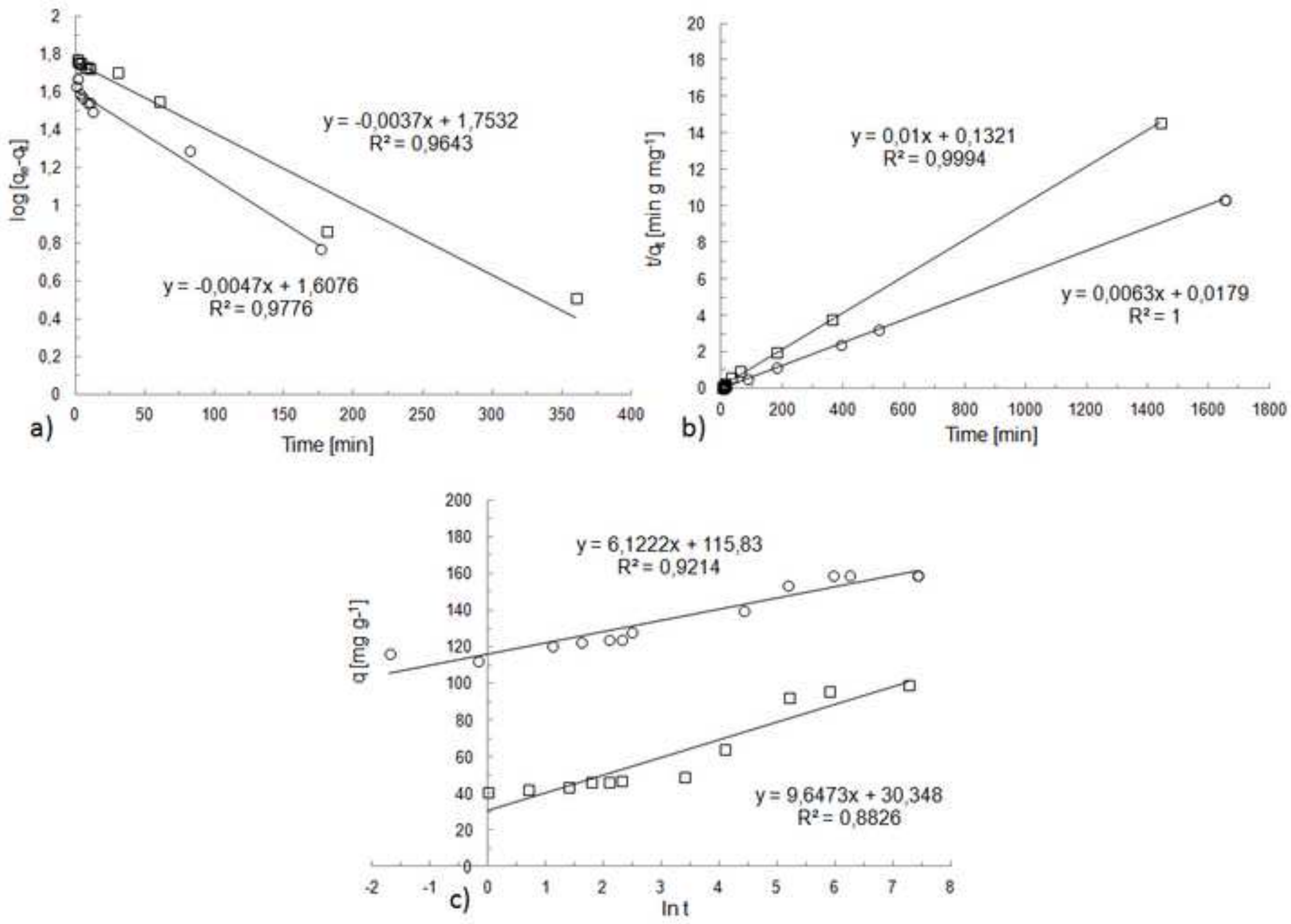


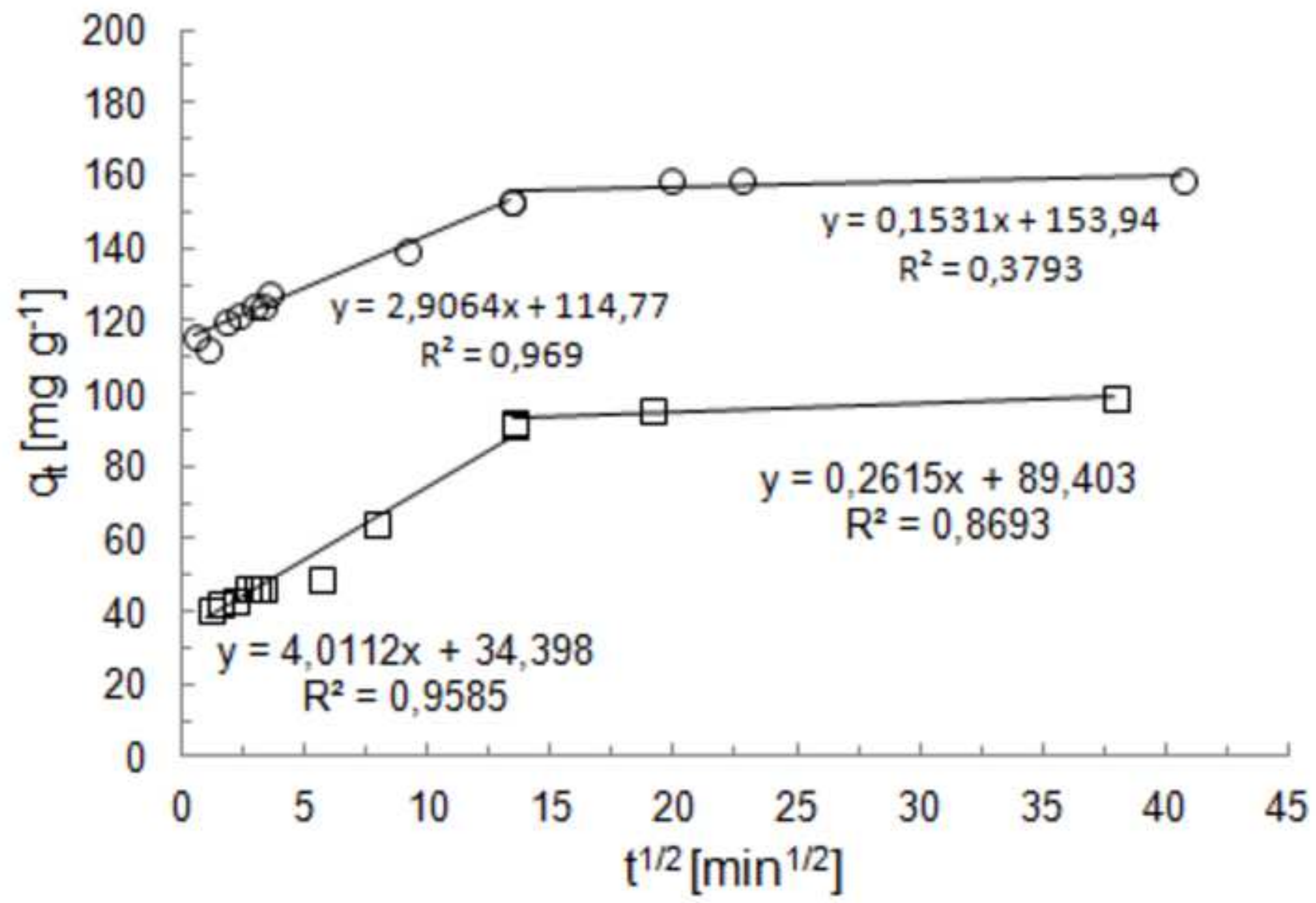


Click here to download high resolution image

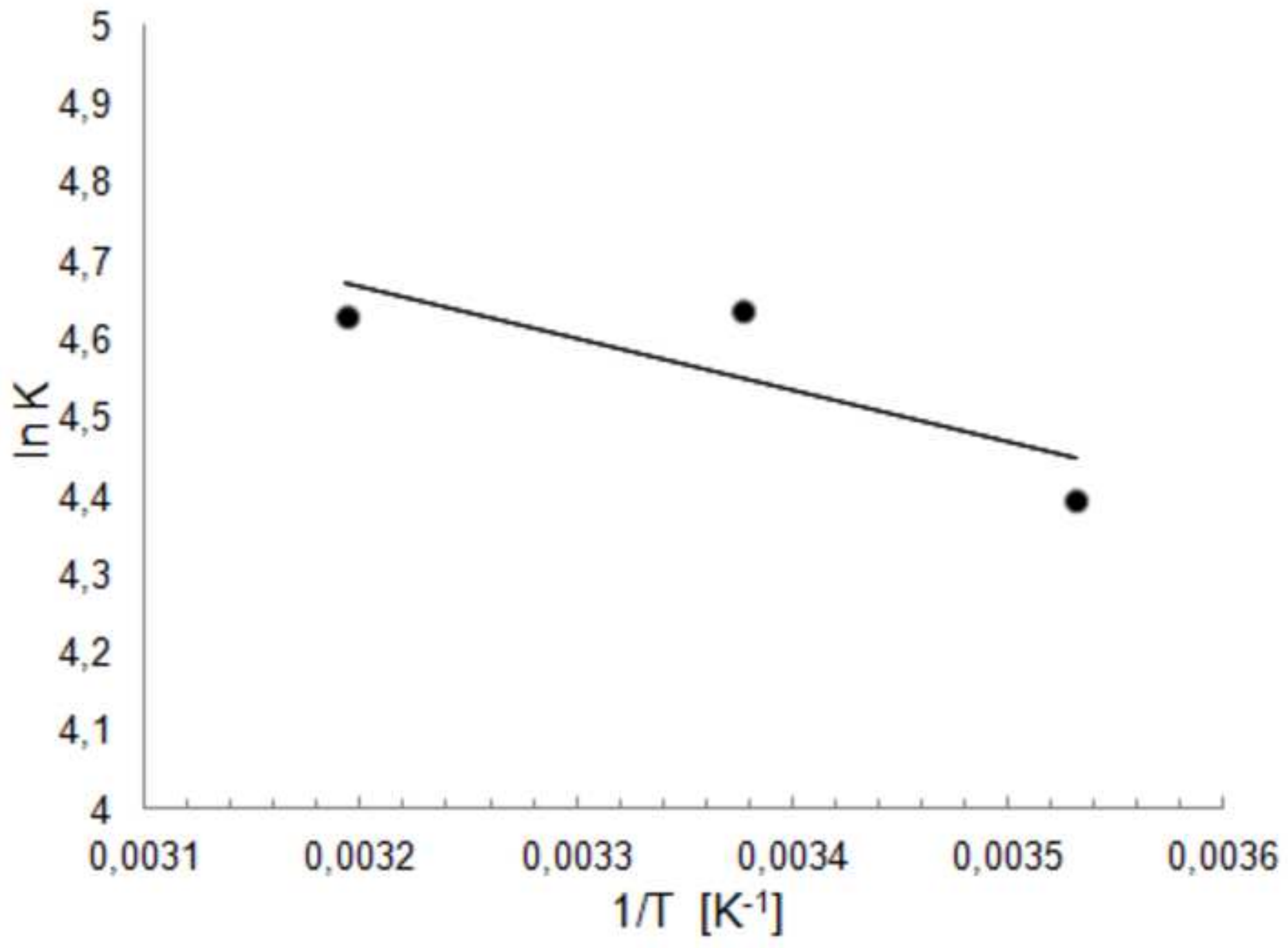


Click here to download high resolution image

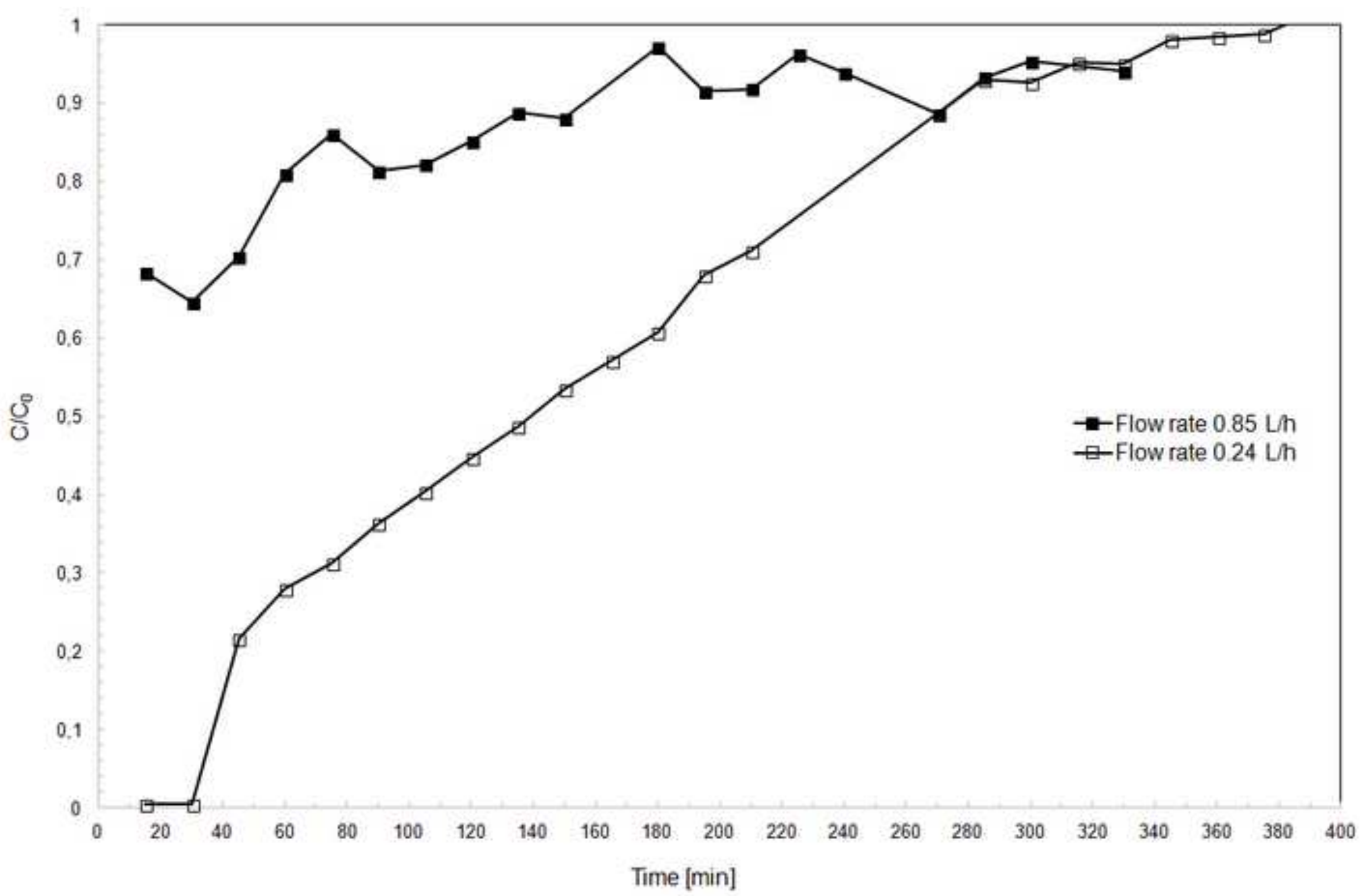


Figure 1. XRD patterns of blast-furnace slag (BFS), blast-furnace-slag geopolymer (BFS-GP) and barium-modified blast-furnace-slag geopolymer (Ba-BFS-GP) samples. $\mathrm{HT}=$ hydrotalcite, $\mathrm{HAT}=$ haturite, $\mathrm{W}=$ witherite.

Figure 2. The FTIR spectra of blast-furnace slag (BFS), barium-modified blast-furnace-slag (Ba-BFS) and barium-modified blast-furnace-slag geopolymer (Ba-BFS-GP).

Figure 3. Total $\mathrm{SO}_{4}{ }^{2-}$ removal per cent (left, solid lines) and total adsorbed amount (right, dashed lines) versus initial $\mathrm{pH}$ on the sorption of $\mathrm{SO}_{4}{ }^{2-}$ from mine effluent. Sorbent dosage: $5 \mathrm{~g} \mathrm{~L}^{-1}$, contact time: $24 \mathrm{~h}$, temperature: $22-23^{\circ} \mathrm{C}$, adsorbate: mine effluent $\left(\mathrm{C}_{0}, \mathrm{SO}_{4}{ }^{2-}: \sim 850-870 \mathrm{mg} \mathrm{L}^{-1}\right)$.

Figure 4. Effect of the initial concentration on the sorption of $\mathrm{SO}_{4}{ }^{2-}$ on Ba-BFS-GP from model solution. Initial pH: $7-8$, sorbent dosage: $5 \mathrm{~g} \mathrm{~L}^{-1}$, contact time: $24 \mathrm{~h}$, temperature: $22-23^{\circ} \mathrm{C}$.

Figure 5. Effect of Ba-BFS-GP dosage on $\mathrm{SO}_{4}{ }^{2-}$ removal. a) Model solution: $\mathrm{C}_{0}\left(\mathrm{SO}_{4}{ }^{2-}\right):{ }^{2} 200 \mathrm{mg} \mathrm{L}^{-1}$, contact time: $3 \mathrm{~h}$. b) Mine effluent: $\mathrm{C}_{0}\left(\mathrm{SO}_{4}{ }^{2-}\right): 865 \mathrm{mg} \mathrm{L}^{-1}$, contact time: $24 \mathrm{~h}$. In both cases initial pH was 7-8.

Figure 6. Bi-Langmuir, Sips, Redlich-Peterson and Toth isotherms of $\mathrm{SO}_{4}{ }^{2-}$ sorption on Ba-BFS-GP. a) Model solution: $\mathrm{C}_{0}\left(\mathrm{SO}_{4}{ }^{2-}\right)$ : $100-1800 \mathrm{mg} \mathrm{L}^{-1}$, sorbent dose: $5 \mathrm{~g} \mathrm{~L}^{-1}$. b) Mine effluent: $\mathrm{C}_{0}\left(\mathrm{SO}_{4}{ }^{2-}\right)$ : $865 \mathrm{mg} \mathrm{L}^{-1}$, sorbent dose: $1.3-15 \mathrm{~g} \mathrm{~L}^{-1}$. Initial pH was 7-8, contact time $24 \mathrm{~h}$ and temperature 22$23^{\circ} \mathrm{C}$.

Figure 7. Effect of contact time on the removal efficiency of $\mathrm{SO}_{4}{ }^{2-}$ onto Ba-BFS-GP. o: Model $\mathrm{SO}_{4}{ }^{2-}$ solution $\left(\mathrm{C}_{0}, \mathrm{SO}_{4}{ }^{2-}: 1100 \mathrm{mg} \mathrm{L}^{-1}\right), \square$ : Mine effluent $\left(\mathrm{C}_{0}, \mathrm{SO}_{4}{ }^{2-}: 853 \mathrm{mg} \mathrm{L}^{-1}\right)$. Initial $\mathrm{pH}: 7-8$, sorbent dosage: $5 \mathrm{~g} \mathrm{~L}^{-1}$, temperature: $22-23^{\circ} \mathrm{C}$.

Figure 8. a) Pseudo-first-order kinetic, b) pseudo-second-order kinetic and c) Elovich model plots of $\mathrm{SO}_{4}{ }^{2-}$ sorption on Ba-BFS-GP. o: Model $\mathrm{SO}_{4}{ }^{2-}$ solution $\left(\mathrm{C}_{0}, \mathrm{SO}_{4}{ }^{2-}: 1100 \mathrm{mg} \mathrm{L}{ }^{-1}\right)$, $\square$ : Mine effluent $\left(\mathrm{C}_{0}, \mathrm{SO}_{4}{ }^{2-}: 853 \mathrm{mg} \mathrm{L}^{-1}\right)$. Initial $\mathrm{pH}: 7-8$, sorbent dosage: $5 \mathrm{~g} \mathrm{~L}^{-1}$, contact time: $24 \mathrm{~h}$, temperature: $22-$ $23^{\circ} \mathrm{C}$. 
Figure 9. Weber and Morris intraparticle diffusion model plot of $\mathrm{SO}_{4}{ }^{2-}$ sorption on Ba-BFS-GP. o: Model $\mathrm{SO}_{4}{ }^{2-}$ solution $\left(\mathrm{C}_{0}, \mathrm{SO}_{4}{ }^{2-}: 1100 \mathrm{mg} \mathrm{L}^{-1}\right)$, $\square$ : Mine effluent $\left(\mathrm{C}_{0}, \mathrm{SO}_{4}{ }^{2-}: 853 \mathrm{mg} \mathrm{L}^{-1}\right)$. Initial pH: 78 , sorbent dosage: $5 \mathrm{~g} \mathrm{~L}^{-1}$, contact time: $24 \mathrm{~h}$, temperature: $22-23^{\circ} \mathrm{C}$.

Figure 10. Van't Hoff plot for adsorption of $\mathrm{SO}_{4}{ }^{2-}$ removal. Initial $\mathrm{pH}: 7-8$, adsorbent dosage $5 \mathrm{~g} \mathrm{~L}^{-1}$, $\mathrm{C}_{0}\left(\mathrm{SO}_{4}{ }^{2-}\right): 1200 \mathrm{mg} \mathrm{L}^{-1}$.

Figure 11. Breakthrough curves of $\mathrm{SO}_{4}{ }^{2-}$ by Ba-BFS-GP packed column for two different flow rates. 
Blast-furnace slag and metakaolin were geopolymerised, modified with barium or treated with a combination of these methods in order to obtain an efficient $\mathrm{SO}_{4}{ }^{2-}$ sorbent for mine water treatment. Of prepared materials, barium-modified blast-furnace slag geopolymer (Ba-BFS-GP) exhibited the highest $\mathrm{SO}_{4}{ }^{2-}$ maximum sorption capacity (up to $119 \mathrm{mg} \mathrm{g}^{-1}$ ) and it compared also favourably to materials reported in the literature. Therefore, Ba-BFS-GP was selected for further studies and the factors affecting to the sorption efficiency were assessed. Several isotherms were applied to describe the experimental results of Ba-BFS-GP and the Sips model showed the best fit. Kinetic studies showed that the sorption process follows the pseudo-second-order kinetics. In the dynamic removal experiments with columns, total $\mathrm{SO}_{4}{ }^{2-}$ removal was observed initially when treating mine effluent. The novel modification method of geopolymer material proved to be technically suitable in achieving extremely low concentrations of $\mathrm{SO}_{4}{ }^{2-}\left(<2 \mathrm{mg} \mathrm{L}^{-1}\right)$ in mine effluents. 